\title{
Burundi: First Review Under the Three-Year Arrangement Under the Poverty Reduction and Growth Facility-Staff Report; Press Release on the Executive Board Discussion; and Statement by the Executive Director for Burundi
}

In the context of the first review under the three-year arrangement under the poverty reduction and growth facility, the following documents have been released and are included in this package:

- $\quad$ The staff report for the First Review Under the Three-Year Arrangement Under the Poverty Reduction and Growth Facility, prepared by a staff team of the IMF, following discussions that ended on November 12, 2008, with the officials of the Burundi on economic developments and policies. Based on information available at the time of these discussions, the staff report was completed on January 8, 2009. The views expressed in the staff report are those of the staff team and do not necessarily reflect the views of the Executive Board of the IMF.

- $\quad$ A Press Release summarizing the views of the Executive Board as expressed during its January 28, 2009 discussion of the staff report that completed the review.

- $\quad$ A statement by the Executive Director for Burundi.

The documents listed below have been or will be separately released.

Enhanced Heavily Indebted Poor Countries (HIPC) Initiative-Completion Point Document and Multilateral Debt Relief Initiative

Poverty Reduction Strategy Paper Annual Progress Report

Joint Staff Advisory Note

Letter of Intent sent to the IMF by the authorities of Burundi*

Memorandum of Economic and Financial Policies by the authorities of Burundi*

Technical Memorandum of Understanding*

*Also included in Staff Report

The policy of publication of staff reports and other documents allows for the deletion of market-sensitive information.

Copies of this report are available to the public from

International Monetary Fund • Publication Services

$70019^{\text {th }}$ Street, N.W. $\bullet$ Washington, D.C. 20431

Telephone: (202) 623-7430 • Telefax: (202) 623-7201

E-mail: publications@imf.org •Internet: http://www.imf.org

\section{International Monetary Fund \\ Washington, D.C.}



INTERNATIONAL MONETARY FUND

BURUNDI

\title{
First Review Under the Three-Year Arrangement Under the Poverty Reduction and Growth Facility
}

\author{
Prepared by the African Department \\ (In consultation with other departments) \\ Approved by Robert Sharer and Dominique Desruelle
}

January 8, 2009

\begin{abstract}
PRGF arrangement: $\quad$ On July 7, 2008, the Executive Board approved a three-year PRGF arrangement with access of SDR 46.2 million (60 percent of quota).
\end{abstract}

Discussions:

Program review:

A mission comprising Mr. Akitoby (head), Mr. Ioannou, and Mr. Thomas (all AFR) visited Bujumbura October 29-November 12, 2008, to conduct the first review of the PRGF-supported program. Mr. de la Piedra (Resident Representative) assisted the mission. Mr. Nintunze (OED) also participated in the discussions. The team and a World Bank mission also held discussions on the HIPC completion point.

The staff met with President Nkurunziza, Second Vice-President Ntisezerana, President of the National Assembly Ntavyohanyuma, Minister of Economy, Finance, and Development Cooperation Nizigama, Central Bank Governor Sindayigaya, other senior officials, and representatives of labor unions, the private sector, NGOs, the donor community, and the media.

All quantitative and structural performance criteria for September 2008 were met, and structural reforms are progressing. Staff recommends completion of the first review of the PRGF-supported program.

HIPC completion point: Board consideration of the HIPC completion point is scheduled along with the first review of the PRGF-supported program.

Publication:
The authorities consent to the publication of this report, the letter of intent, the MEFP, the HIPC completion point document, and the annual progress report on the PRSP. 


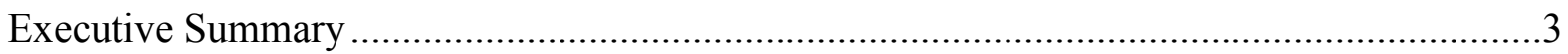

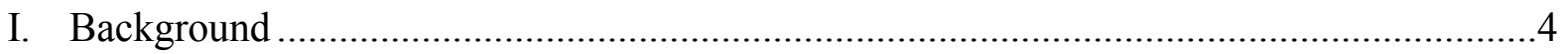

II. Recent Developments and Performance Under the PRGF .........................................4

III. Consolidating Economic Stability and Sustaining Growth.........................................

A. Macroeconomic Outlook...................................................................................

B. Fiscal Policy and Related Reforms................................................................ 8

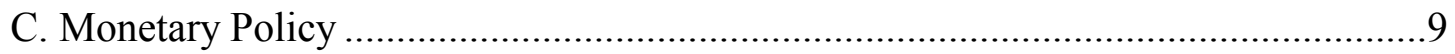

D. External Sector Policies ........................................................................... 9

E. Structural Reforms.................................................................................. 10

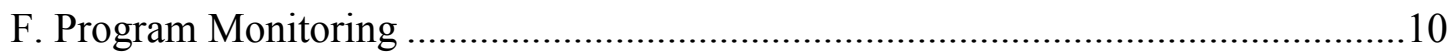

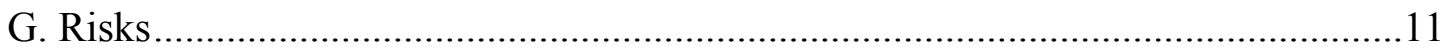

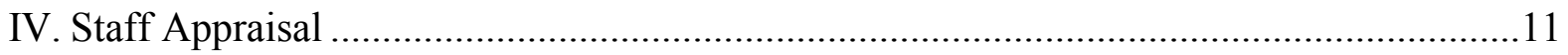

Figure

1. Recent Macroeconomic Performance, 2000-08 ...............................................................6

Tables

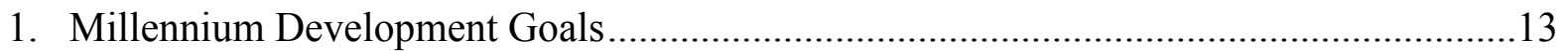

2. Selected Economic and Financial Indicators, 2007-12 ...............................................14

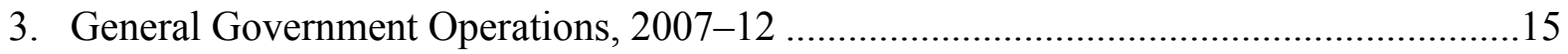

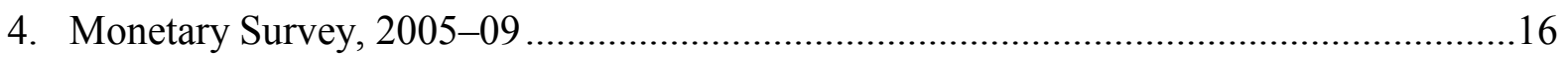

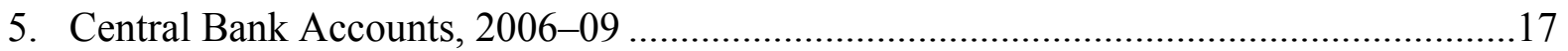

6. Balance of Payments, 2007-12 ...................................................................................... 18

7. Actual and Projected Schedule of PRGF Disbursements and Reviews, 2008-11 ............19

8. Banking System Soundness Indicators, 2005-08 ...................................................20

Appendices

1. Letter of Intent......................................................................................................2 21

Attachment I. Memorandum of Economic and Financial Policies ......................23

Attachment II. Technical Memorandum of Understanding ................................37 


\section{EXECUTIVE SUMMARY}

Recent developments. Economic growth increased to 4.5 percent in 2008, mainly because of a good coffee harvest and more donor-financed projects. Inflation surged to 22 percent in 2008, driven by higher food and energy prices earlier in the year. The economic outlook is generally positive but subject to risks arising from the security situation and the external environment.

Performance under the PRGF-supported program has been broadly satisfactory. All quantitative and structural performance criteria at end-September 2008 were met, and structural reforms are proceeding. Parliament has passed the new central bank charter, the budget organic law, and the investment code.

The program for $\mathbf{2 0 0 9}$ seeks to reduce inflation to single digits and further reduce poverty. Prudent monetary policy will help anchor inflation expectations while allowing sufficient scope for economic growth. Fiscal policy will consolidate progress on strengthening domestic revenue and reallocating spending to MDG-related sectors. Structural reforms will continue to focus on public financial management and central bank safeguards.

Risks to the program are significant. The foremost risk is a worsening political, social, and security situation, though the recent power-sharing agreement between the government and the last rebel group could help contain it. Other risks are governance slippages and worse-than-expected effects of the international financial crisis.

Staff recommends completion of the first review based on Burundi's performance and policy commitments. 


\section{BACKGROUND}

1. Burundi is one of the least developed countries in the world. GDP per capita is about US\$139. While the country is making progress toward the Millennium Development Goals (MDGs), it is unlikely that any will be achieved by 2015 (Table 1).

2. Burundi is emerging from more than a decade of civil conflict. The security situation deteriorated in April 2008 when the last rebel group, Forces Nationales pour la Libération (FNL), abandoned peace negotiations and attacked the capital, Bujumbura. Hostilities ended when a cease-fire agreement was signed in May. In December, the government and the FNL reached an agreement on power-sharing. If implemented, it should help ensure the restoration of peace. General elections are scheduled for 2010.

3. In a difficult postconflict environment, Burundi made steady, though uneven, progress in the first PRGF arrangement (2004-08). At the conclusion of the final review, Executive Directors urged the authorities to strengthen public financial management (PFM) and move forward with structural reforms to improve the business climate and spur growth.

\section{The World Bank Board in August 2008 approved a new country assistance} strategy that focuses on structural reforms to further increase growth and reduce poverty. The Joint World Bank-IMF Work Program is described in the Informational Annex.

\section{Recent Developments And Performance Under the PRGF}

5. Economic growth accelerated and inflation increased in 2008 (Figure 1 and Table 2). As the program forecast, real GDP grew at 4.5 percent, up from 3.6 percent in 2007 , mainly because of a good coffee harvest and donor-financed investment projects. With international commodity prices higher in the first seven months, year-on-year inflation is expected to reach 22 percent by year-end, ${ }^{1}$ far above the 14 percent the program envisaged. Between January and September 2008, the nominal exchange rate depreciated by 4 percent, while the real effective exchange rate appreciated by 13 percent.

\section{The authorities' response to the food and oil shock has been broadly}

appropriate. Customs duties and transaction taxes on imports of certain food and oil products have been temporarily suspended. To preserve the overall tax collection levels, tariffs on oil products consumed by high-income households was raised and revenue

\footnotetext{
${ }^{1}$ For more information on how the food and fuel shock affected inflation in the countries of the East African Community (EAC), see Murgasova et al. (2008), "Impact of Rising International Food and Fuel Prices on Inflation in the EAC Countries," IMF Selected Issues Paper.
} 
administration was strengthened. The authorities also sought to mitigate the impact of higher food and oil prices on the poor by enhancing social safety nets (e.g., food security programs and school feeding programs). To boost food output, they distributed seeds and fertilizers to smallholders, provided micro-credits, and rehabilitated irrigations systems. The budgetary impact of these policy responses (estimated at about 3 percent of GDP) was fully financed by donors.

\section{Performance under the PRGF-supported program has been broadly}

satisfactory. The overall fiscal deficit (cash basis, including non-HIPC grants) is estimated at about 4.4 percent of GDP, slightly below the target of 4.9 percent. Domestic revenue is estimated to be in line with the target of 19.1 percent of GDP. Total spending was higher than expected by about 2.5 percent of GDP, mostly because of aid-financed spending to boost food output and mitigate the impact of higher food and oil prices on the poor. The wage bill was 0.2 percent of GDP higher than programmed, reflecting higher payrolls in the social sectors. Because fiscal performance was better, net domestic assets were lower than programmed, but reserve money was higher because net international reserves declined less than programmed. All quantitative performance criteria were met (Appendix I, Table 3). 
Figure 1. Recent Macroeconomic Performance, 2000-08

Growth was volatile but trended upward...

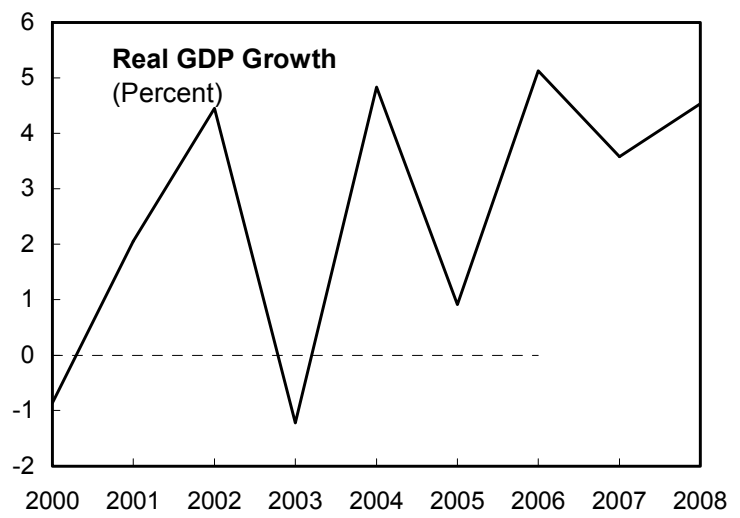

The fiscal position has improved...

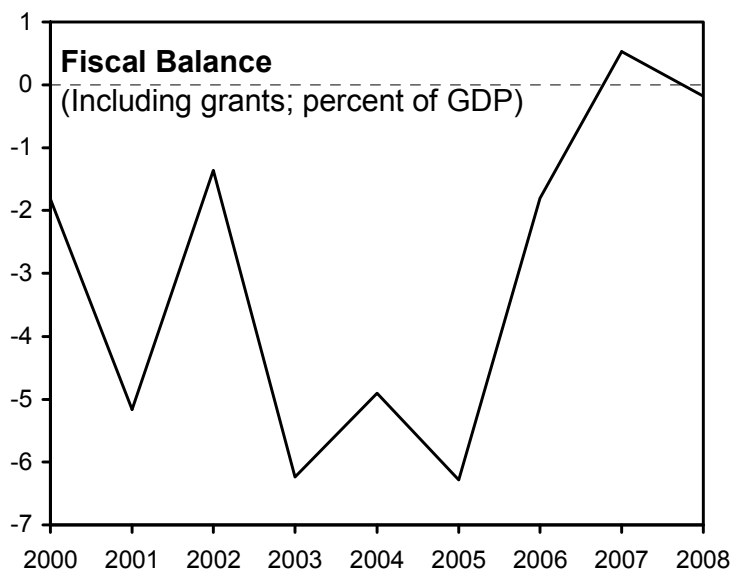

The current account deteriorated...

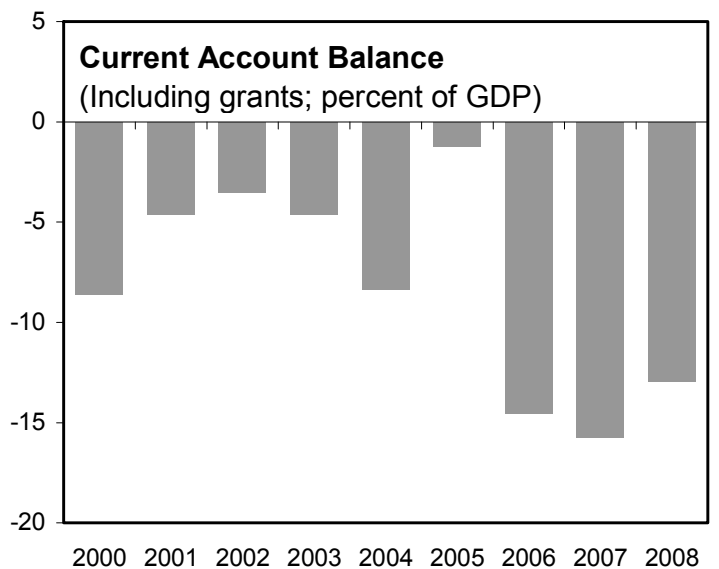

Sources: Burundi authorities; and IMF staff estimates. ...while inflation has accelerated sharply.

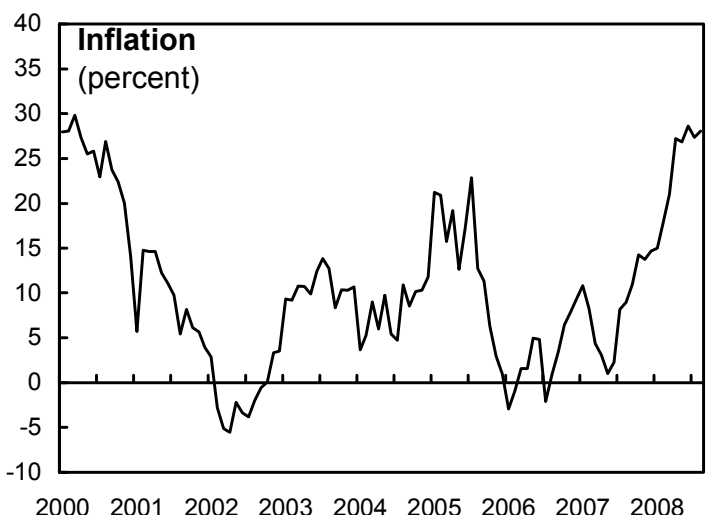

... as external grants have increased.

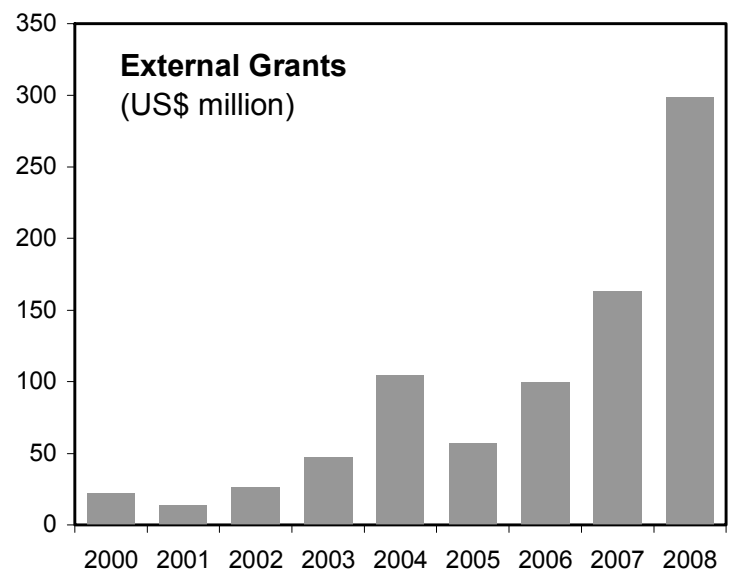

...but official inflows helped rebuild international reserves.

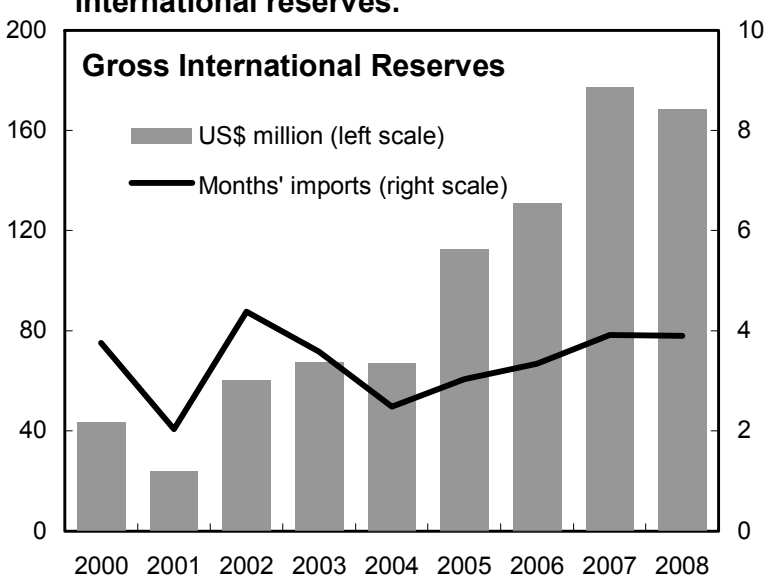


8. Structural reforms are moving ahead (MEFP $\$ 6$ ). In particular, Parliament has passed the new central bank charter, the budget organic law, and the investment code, among other laws. The census of government civil employees has been completed (structural performance criterion for end-September 2008), and censuses of military and police personnel have begun.

\section{Consolidating Economic Stability and Sustaining Growth}

9. The authorities stressed that they intend to consolidate macroeconomic stability and further reduce poverty. They recognized that, while the HIPC Initiative and MDRI debt relief will reduce Burundi's heavy debt burden, they should maintain prudent fiscal and monetary policies and rely mainly on grants and highly concessional loans to avoid unsustainable debt.

\section{A. Macroeconomic Outlook}

10. The near-term economic outlook is influenced by the adverse impact of the international financial crisis (Text Table 1). Real GDP growth is projected to grow by 4.5 percent in 2009, down by half a percentage point from staff projections in June 2008 (IMF Country Report No. 08/282). This downward revision reflects slackened global demand owing to the global financial crisis. Growth in 2009 will be driven by: (1) some rebound in food production (the principal source of economic growth); (2) the positive supply shock arising from falling oil prices; and (3) a substantial increase in investment during 2008-09. The authorities are aware that the near-term growth is subject to downside risks arising from the unfolding financial crisis ( $\$ 28)$. Because international oil prices are falling, headline inflation is projected to peak in 2008 at 22 percent before declining to 9 percent in 2009. Gross official reserves would decline slightly to about $3 \frac{1}{2}$ months of imports.

11. Provided the security situation continues to improve, Burundi's medium-term economic outlook appears to be positive (Text Table 1). Medium-term GDP growth is expected to average 4.8 percent over 2008-12. Inflation is expected to decelerate to $51 / 2$ percent by 2012. Gross official reserves would stabilize at about 3 months of imports.

12. The projected growth pattern, which resembles those observed in other postconflict countries, is predicated on three factors: (1) continued removal of major economic distortions, especially in the coffee sector, which will boost total factor productivity; (2) a substantial increase in investment, driven by international aid and largely for infrastructure renovation, which will help relieve major supply bottlenecks; and (3) further advances in trade liberalization following accession to the EAC, which will help diversify the economy, stimulate competition, and attract more investment. 
Text Table 1. Burundi: Medium-Term Outlook, 2007-12

\begin{tabular}{|c|c|c|c|c|c|c|c|c|}
\hline & \multirow{2}{*}{$\frac{2007}{\text { Est. }}$} & \multicolumn{2}{|c|}{2008} & 2009 & 2010 & 2011 & 2012 & 2008-12 \\
\hline & & Prog. & Proj. & \multicolumn{4}{|c|}{ Proj. } & Average \\
\hline & \multicolumn{8}{|c|}{ (Annual percentage change) } \\
\hline \multicolumn{9}{|l|}{ National income and prices } \\
\hline Real GDP growth & 3.6 & 4.5 & 4.5 & 4.5 & 5.0 & 5.0 & 5.0 & 4.8 \\
\hline \multirow[t]{2}{*}{ Consumer prices (end of period) } & 14.7 & 14.0 & 22.0 & 9.0 & 7.5 & 6.0 & 5.5 & 10.0 \\
\hline & \multicolumn{8}{|c|}{ (Percent of GDP, unless otherwise indicated) } \\
\hline \multicolumn{9}{|l|}{ General government } \\
\hline Revenue (excluding grants) & 18.6 & 19.1 & 19.1 & 19.3 & 19.4 & 19.5 & 19.6 & 19.4 \\
\hline Total expenditure and net lending & 38.5 & 42.6 & 44.8 & 44.6 & 43.4 & 41.8 & 41.2 & 43.1 \\
\hline \multicolumn{9}{|l|}{ Overall balance } \\
\hline Commitment basis (after non-HIPC grants) & -3.3 & -3.6 & -3.2 & -3.0 & -2.6 & -2.5 & -2.1 & -2.7 \\
\hline Cash basis (after non-HIPC grants) & -5.4 & -4.9 & -4.4 & -3.0 & -2.6 & -2.5 & -2.1 & -2.9 \\
\hline \multicolumn{9}{|l|}{ External sector } \\
\hline Current account balance & -15.7 & -18.2 & -13.0 & -11.5 & -10.1 & -12.1 & -13.7 & -12.1 \\
\hline \multicolumn{9}{|l|}{ Gross official reserves } \\
\hline In US\$ millions & 177.3 & 155.3 & 168.4 & 153.8 & 145.5 & 153.4 & 161.7 & 156.6 \\
\hline In months of imports & 3.9 & 3.2 & 3.9 & 3.4 & 3.0 & 3.0 & 3.0 & 3.3 \\
\hline
\end{tabular}

Sources: Burundi authorities; and IMF staff estimates and projections.

\section{B. Fiscal Policy and Related Reforms}

13. The fiscal program targets an overall fiscal deficit (on a commitment basis and after non-HIPC grants) of 3 percent of GDP. To help contain inflation and crowd in the private sector, net domestic financing in 2009 is programmed at zero for the year as a whole. Staff and authorities agreed that fiscal policy will continue to support the use of aid, with a view to allowing increased spending in areas critical to meeting the MDGs. To this end, taking into account absorptive capacity, the program will accommodate a higher fiscal deficit if concessional external financing is greater than expected. The authorities are continuing to work with the World Bank to improve absorptive capacity.

\section{The authorities recognize that mobilizing domestic revenue is critical for fiscal} sustainability and increased poverty-reducing expenditure (MEFP, $\mid 10$ ). The revenue target in the 2009 budget is about 19 percent of GDP. Moreover, with Burundi's accession to the East African Community (EAC), the authorities will introduce a value-added tax (VAT) to replace a transaction tax and adopt the EAC common external tariff in July 2009. Both are expected to have a positive impact on revenue in the medium term. However, to protect domestic revenue in the early stages of tax reform, the authorities will (1) adopt a VAT rate that is 1 percentage point higher than the transaction tax; (2) broaden the tax base by reducing exemptions; (3) step up recovery of tax arrears; and (4) phase out the temporary suspension of tax levies on oil products, taking into account the social impact on the poor (MEFP, $₫ 11)$.

15. The 2009 budget consolidates progress on reallocating spending to MDG-related sectors, supported by HIPC and MDRI debt relief (MEFP, $\mid 12-15)$. Spending on priority 
sectors is expected to increase from 8.8 percent in 2008 to 9.9 percent in 2009. In line with Burundi's poverty reduction strategy, over the next two years, MDRI resources will be spent on agriculture, water, rural infrastructure, health, and education. The budget expands the coverage of foreign-financed projects, reflecting efforts to improve collection of data on spending in social sectors. To provide more space for propoor spending, the wage bill is projected to decline from 11 percent of GDP in 2008 to 10.7 percent of GDP in 2009, consistent with the objective of bringing the wage bill below 10 percent of GDP in the medium term.

\section{Monetary Policy}

16. The overriding monetary objective is to stabilize prices while allowing sufficient scope for economic growth (MEFP, $\mid 20-22$ ). To bring down inflation from 22 percent in 2008 to high single digits in 2009 , broad money growth is programmed to decline to about 14 percent, while allowing for increased credit to the private sector. Given concerns about inflation, an indicative target for reserve money has been added to the program. Staff envisages reserve money growth in 2009 to be about 13 percent. With MCM technical assistance (TA), the authorities are working to improve liquidity management.

17. The Ministry of Finance and the central bank agreed that close coordination of fiscal and monetary policies is essential to achieving the inflation target. They share the view that such cooperation is needed to improve the central bank's liquidity forecast and ensure that aid-financed expenditures are adequately absorbed through sales of foreign exchange. Regular meetings between officials of both institutions would focus on how the government's cash outlays affect reserve money and foreign exchange market operations.

18. Consequent to the international financial crisis, the central bank is moving to enhance banking supervision (MEFP, $\{31$ ). Burundi's financial system is underdeveloped and has no significant links to international capital markets. Although there have been no obvious signs of imminent systemic stress, staff urged the authorities to step up implementation of the MCM recommendations on banking supervision. The joint Bank-Fund FSAP mission planned for January 2009 will offer a timely opportunity to guide the central bank on a financial sector reform strategy and a more comprehensive policy response to risks arising from the global financial crisis.

\section{External Sector Policies}

19. External developments in $\mathbf{2 0 0 9}$ are expected to be dominated by the decline in commodity prices owing to the international financial crisis. The projected decline in international food and oil prices will lower Burundi's import bill by about 18 percent (food and oil imports comprise one-fourth of total imports), but lower coffee prices will reduce total exports by about 12 percent. Overall, the current account deficit (including official 
transfers) will narrow slightly to 11.5 percent of GDP. Gross official reserves are expected to decline to about $3 \frac{1}{2}$ months of imports.

20. More proactive management of foreign exchange reserves will facilitate implementation of program policies (MEFP, $\mid 23$ ). With MCM TA, the authorities are moving to improve the system of foreign exchange auctions while preparing the groundwork for development of an interbank foreign exchange market in the medium term. Staff also urged the authorities to take steps to eliminate the remaining multiple currency practice and accept the obligations of Article VIII, Section 2, 3, and 4. The authorities intend to request Fund TA in this regard.

\section{The authorities should continue to strengthen external debt management} following the HIPC completion point and MDRI relief. Accordingly to the latest LIC DSA, Burundi's external debt burden indicators are expected to remain high over the medium term. While debt relief would significantly reduce Burundi's external debt burden, the country will still be vulnerable to external exogenous shocks. This underscores the importance of continuing to seek only highly concessional loans and grants.

\section{The government has established an interministerial committee to coordinate}

EAC integration efforts and facilitate decision-making. A national strategy and action plan, prepared with the assistance of development partners, will be adopted soon.

\section{E. Structural Reforms}

23. The authorities are committed to reforming public financial management (PFM) (MEFP, ๆ25-27). The council of ministers will adopt a PFM strategy and action plan. To facilitate gradual implementation of the single Treasury account, the government will step up rationalization of government bank accounts. The government in 2009 will begin phasing in the new budget organic law.

24. Reforms are underway in the coffee sector (MEFP, $\mid 33$ ). Implementation of new regulations has already resulted in increased competition and transparency. With World Bank assistance, the government also adopted a comprehensive reform of the coffee sector.

\section{F. Program Monitoring}

25. Semiannual quantitative performance criteria focus on net foreign assets and net domestic assets of the central bank and net domestic financing of the government, with adjusters to deal with aid volatility. There are also three continuous performance criteria, with zero ceilings for (i) new nonconcessional external debt contracted or guaranteed; (ii) shortterm external debt; and (iii) accumulation of external arrears. Indicative targets have been established for the government wage bill, accumulation of domestic arrears, and reserve money (MEFP, Table 4). 
26. The indicative target on the wage bill would protect nonwage priority spending. To tackle the root causes of wage-related fiscal problems, the program also envisages structural conditionality on the civil service census and payroll management. Staff will assess progress on these measures during program reviews and remove the wage-bill ceiling if appropriate.

27. The proposed structural conditionality is linked to the first strategic axis of the PRSP, namely strengthening economic governance (especially transparent management of government finance). Table 2 of the MEFP shows prior actions - all completed - and Table 5 describes structural conditionality.

\section{G. Risks}

28. The authorities have reiterated their firm commitment to the program and to good governance, but there are two main risks:

- $\quad$ First, the impact of the global financial crisis on economic growth could be worse than expected. Real GDP growth is subject to downside risks of reduced demand for exports and more pronounced decline in coffee prices. Should these risks materialize, the authorities have put in place a contingency plan to safeguard the program objectives, in the event of lower tax revenue (MEFP, \19). The financial crisis could also lead donors to scale back their financial support. To deal with unexpected aid shortfall, the program includes target adjusters (see TMU).

- $\quad$ Second, a worsening political, social, and security situation would be a major setback. The cease-fire agreement between the government and the last rebel group, FNL, laid the foundation for peace, but implementation of the recent power-sharing agreement is critical.

\section{StafF Appraisal}

29. In a difficult post-conflict environment, Burundi has made steady, though uneven, progress. Real GDP accelerated in 2008, though the recent food and fuel shock has kept inflation high. Most monetary and fiscal reforms have progressed well. The economic outlook is generally positive but subject to risks arising from the security situation and the external environment.

30. The program for 2009 should further consolidate macroeconomic stability and reduce poverty. Prudent monetary policy will help anchor inflation expectations while allowing sufficient scope for economic growth. Spending on MDG-related sectors will be boosted significantly, supported by HIPC Initiative and MDRI debt relief. 
31. The authorities should continue to rely mainly on grants and highly concessional loans to keep debt sustainable. Improvements in governance will be critical for donor support. To this end, the authorities should further strengthen PFM.

32. In light of the global financial crisis, staff urges the authorities to step up their efforts to strengthen the financial sector by improving banking supervision; addressing weaknesses in the banking system; and enhancing central bank internal controls and risk management systems. The January Bank-Fund FSAP mission will help guide these efforts.

33. Sustained growth depends on accelerating structural reforms. In addition to maintaining the momentum on fiscal governance reforms, the authorities should continue their efforts to reform the coffee sector. EAC membership should also spur structural reforms that would improve the business environment.

34. In a postconflict country, risks to the program remain significant, but so far the authorities have demonstrated their ability to manage economic and social pressures. Staff fully endorses the authorities' efforts.

35. Staff recommends completion of the first review, based on Burundi's performance and the strength of the program. 
Table 1. Burundi: Millennium Development Goals

\begin{tabular}{|c|c|c|c|c|c|c|c|}
\hline & 1990 & 1995 & 2001 & 2003 & 2004 & 2005 & $\begin{array}{r}2015 \\
\text { Target } \\
\end{array}$ \\
\hline \multicolumn{8}{|l|}{ Goal 1. Eradicate extreme poverty and hunger } \\
\hline \multicolumn{8}{|l|}{$\begin{array}{l}\text { Target 1: Halve between } 1990 \text { and } 2015 \text {, the proportion of people whose income is less } \\
\text { than US } \$ 1 \text { a day. }\end{array}$} \\
\hline 1. Population below US\$1 a day (percent) & $\ldots$ & $\ldots$ & $58.4^{1}$ & $\ldots$ & $\ldots$ & $\ldots$ & $\ldots$ \\
\hline 2. Poverty gap ratio at US\$1 a day (percent) & $\ldots$ & $\ldots$ & $22.7^{1}$ & $\ldots$ & $\ldots$ & $\ldots$ & $\ldots$ \\
\hline 3. Share of income or consumption held by poorest 20 percent (percent) & $7.9^{2}$ & $\ldots$ & $5.1^{1}$ & $\ldots$ & $\ldots$ & $\ldots$ & $\ldots$ \\
\hline \multicolumn{8}{|l|}{ Target 2: Halve between 1990 and 2015 the proportion of people suffering hunger } \\
\hline 4. Prevalence of child malnutrition (percent of children under 5) & $\ldots$ & $\ldots$ & $45.1^{3}$ & $\ldots$ & $\ldots$ & $\ldots$ & $\ldots$ \\
\hline 5. Population below minimum level of dietary energy consumption (percent) & 49.0 & 64.0 & 70.0 & 67.0 & $\ldots$ & 66.0 & 24.5 \\
\hline \multicolumn{8}{|l|}{ Goal 2. Achieve universal primary education } \\
\hline \multicolumn{8}{|l|}{$\begin{array}{l}\text { Target 3: Ensure that, by 2015, children will be able to complete a full course of primary } \\
\text { schooling. }\end{array}$} \\
\hline 6. Net primary enrollment ratio (percent of relevant age group) & 41.0 & 29.5 & 52.3 & 30.6 & $\ldots$ & 35.7 & 100.0 \\
\hline 7. Percentage of cohort reaching grade 5 & 61.7 & $\ldots$ & 64.0 & 63.0 & $\ldots$ & 67.0 & 100.0 \\
\hline 8. Youth literacy rate (percent age $15-24$ ) & 51.6 & 57.9 & 65.1 & $\ldots$ & 73.3 & $\ldots$ & 100.0 \\
\hline \multicolumn{8}{|l|}{ Goal 3. Promote gender equality and empower women } \\
\hline \multicolumn{8}{|l|}{$\begin{array}{l}\text { Target 4: Eliminate gender disparity in primary and secondary education preferably by } \\
2005 \text { and to all levels of education by } 2015 \text {. }\end{array}$} \\
\hline 9. Ratio of girls to boys in primary and secondary education (percent) & 81.8 & $\ldots$ & $\ldots$ & 79.1 & 82.0 & 82.8 & $\ldots$ \\
\hline 10. Ratio of young literate females to males (percent ages $15-24$ ) & 76.7 & 86.0 & 95.6 & $\ldots$ & 91.7 & $\ldots$ & $\ldots$ \\
\hline 11. Share of women employed in the nonagricultural sector (percent) & 13.3 & $\ldots$ & $\ldots$ & $\ldots$ & $\ldots$ & $\ldots$ & $\ldots$ \\
\hline 12. Proportion of seats held by women in the national parliament (percent) & $\ldots$ & 11.3 & 14.0 & 18.0 & 18.0 & 30.5 & $\ldots$ \\
\hline \multicolumn{8}{|l|}{ Goal 4. Reduce child mortality } \\
\hline \multicolumn{8}{|l|}{ Target 5: Reduce by two-thirds between 1990 and 2015 the under- 5 mortality rate } \\
\hline 13. Under-5 mortality rate (per 1,000 ) & 190.0 & 190.0 & 204.0 & $\ldots$ & 190.0 & 190.0 & 63.3 \\
\hline 14. Infant mortality rate (per 1,000 live births) & 114.0 & 114.0 & 121.0 & $\ldots$ & 114.0 & 114.0 & $\ldots$ \\
\hline 15. Immunization against measles (percent of children $12-23$ months) & 74.0 & 80.0 & 75.0 & 75.0 & 75.0 & 75.0 & $\ldots$ \\
\hline \multicolumn{8}{|l|}{ Goal 5. Improve maternal health } \\
\hline \multicolumn{8}{|l|}{ Target 6: Reduce by three-quarters, between 1990 and 2015 , the maternal mortality ratio. } \\
\hline 16. Maternal mortality ratio (modeled estimate, per 100,000 live births) & $\ldots$ & $\ldots$ & $1,000.0^{3}$ & $\ldots$ & $\ldots$ & $\ldots$ & $\ldots$ \\
\hline 17. Proportion of births attended by skilled health personnel (precent of total) & $\ldots$ & $\ldots$ & $25.2^{3}$ & $\ldots$ & $\ldots$ & $\ldots$ & $\ldots$ \\
\hline \multicolumn{8}{|l|}{ Goal 6. Combat HIVIAIDS, malaria and other diseases } \\
\hline \multicolumn{8}{|l|}{ Target 7: Halt by 2015 , and begin to reverse, the spread of HIVIAIDS. } \\
\hline 18. HIV prevalence among females (percent ages 15-24) & $\ldots$ & $\ldots$ & 11.0 & $\ldots$ & $\ldots$ & 2.3 & $\ldots$ \\
\hline 19. Contraceptive prevalence rate (percent of women ages 15-49) & $\ldots$ & $\ldots$ & $16.0^{3}$ & $\ldots$ & $\ldots$ & & $\ldots$ \\
\hline 20. Number of children orphaned by HIVIAIDS & $\ldots$ & $\ldots$ & 170,000 & 120,000 & $\ldots$ & 120,000 & $\ldots$ \\
\hline \multicolumn{8}{|l|}{$\begin{array}{l}\text { Target } 8 \text { : Halt by } 2015 \text {, and begin to reverse, the incidence of malaria and other major } \\
\text { diseases. }\end{array}$} \\
\hline 21. Prevalence of death associated with malaria & $\ldots$ & $\ldots$ & $\ldots$ & $\ldots$ & $\ldots$ & $\ldots$ & $\ldots$ \\
\hline 22. Share of population in malaria risk areas using effective prevention and treatment & $\ldots$ & $\ldots$ & $\ldots$ & $\ldots$ & $\ldots$ & $\ldots$ & $\ldots$ \\
\hline 23. Incidence of tuberculosis (per 100,000 people) & 124.6 & $\ldots$ & 298.3 & 334.2 & $\ldots$ & 333.7 & $\ldots$ \\
\hline 24. Tuberculosis cases detected by DOTS (percent) & $\ldots$ & 19.6 & 34.4 & 30.0 & 28.9 & 29.6 & $\ldots$ \\
\hline \multicolumn{8}{|l|}{ Goal 7. Ensure environmental sustainability } \\
\hline Target 9: Integrate the principles of sustainable development into policies and program & & & & & & & \\
\hline Reverse the loss of environmental resources. & & & & & & & \\
\hline 25. Forest area (percent of total land area) & 11.3 & $\ldots$ & $\ldots$ & $\ldots$ & $\ldots$ & 5.9 & $\ldots$ \\
\hline 26. Nationally protected areas (percent of total land area) & 4.4 & 4.8 & 5.6 & 5.6 & 5.6 & 5.7 & $\ldots$ \\
\hline 27. GDP per unit of energy use (PPP US\$ per kg oil equivalent) & $\ldots$ & $\ldots$ & $\ldots$ & & $\ldots$ & $\ldots$ & $\ldots$ \\
\hline 28. $\mathrm{CO}_{2}$ emissions (metric tons per capita) & 0.03 & 0.04 & 0.04 & 0.03 & $\ldots$ & $\ldots$ & $\ldots$ \\
\hline 29. Proportion of population using solid fuels & & & & & & & \\
\hline Target 10: Halve by 2015 proportion of people without access to safe drinking water. & & & & & & & \\
\hline 30. Access to improved water source (percent of population) & 69.0 & $\ldots$ & $\ldots$ & $\ldots$ & 79.0 & 79.0 & 84.5 \\
\hline $\begin{array}{l}\text { Target 11: Achieve by } 2020 \text { significant improvement for at least } 100 \text { million slum dwelle } \\
\text { worldwide. }\end{array}$ & & & & & & & \\
\hline 31. Access to improved sanitation (percent of population) & 44.0 & $\ldots$ & $\ldots$ & $\ldots$ & 36.0 & 36.0 & $\ldots$ \\
\hline 32. Access to secure tenure (percent of population) & $\ldots$ & $\ldots$ & $\ldots$ & $\ldots$ & $\ldots$ & $\ldots$ & $\ldots$ \\
\hline Goal 8. Develop a Global Partnership for Development ${ }^{4 /}$ & & & & & & & \\
\hline Target 16: Develop and implement strategies for productive work for youth. & & & & & & & \\
\hline 45. Unemployment rate of population ages $15-24$ (total) & $\ldots$ & $\ldots$ & $\ldots$ & $\ldots$ & $\ldots$ & $\ldots$ & $\ldots$ \\
\hline Female & $\ldots$ & $\ldots$ & $\ldots$ & $\ldots$ & $\ldots$ & $\ldots$ & $\ldots$ \\
\hline Male & $\ldots$ & $\ldots$ & $\ldots$ & $\ldots$ & $\ldots$ & $\ldots$ & $\ldots$ \\
\hline Target 17: Provide access to affordable essential drugs. & & & & & & & \\
\hline 46. Proportion of population with access to affordable essential drugs & $\ldots$ & $\cdots$ & $\cdots$ & $\ldots$ & $\ldots$ & $\cdots$ & $\ldots$ \\
\hline $\begin{array}{l}\text { Target 18: Make available new technologies, especially information and communicati } \\
\text { 47. Fixed line and mobile telephones (per } 1,000 \text { people) }\end{array}$ & & & & & & & \\
\hline $\begin{array}{l}\text { 47. Fixed line and mobile telephones (per } 1,000 \text { people) } \\
\text { 48. Personal computers (per } 1,000 \text { people) }\end{array}$ & $\begin{array}{r}1.4 \\
\ldots\end{array}$ & $\begin{array}{r}2.9 \\
\ldots\end{array}$ & $\begin{array}{l}7.4 \\
0.7\end{array}$ & $\begin{array}{r}12.5 \\
1.8\end{array}$ & $\begin{array}{r}12.5 \\
4.8\end{array}$ & $\begin{array}{r}17.6 \\
4.7\end{array}$ & $\cdots$ \\
\hline
\end{tabular}

Sources: World Bank; World Development Indicators database, April 2006; and IMF staff estimates.

${ }^{1}$ Survey data for 1998.

${ }^{2}$ Survey data for 1992 .

${ }^{3}$ Survey data for 2000 .

${ }^{4}$ Targets $12-15$ and indicators 33-44 are excluded because they cannot be measured on a country-specific basis. These are related to official development assistance, market access, and the HIPC Initiative. 
Table 2. Burundi: Selected Economic and Financial Indicators, 2007-12

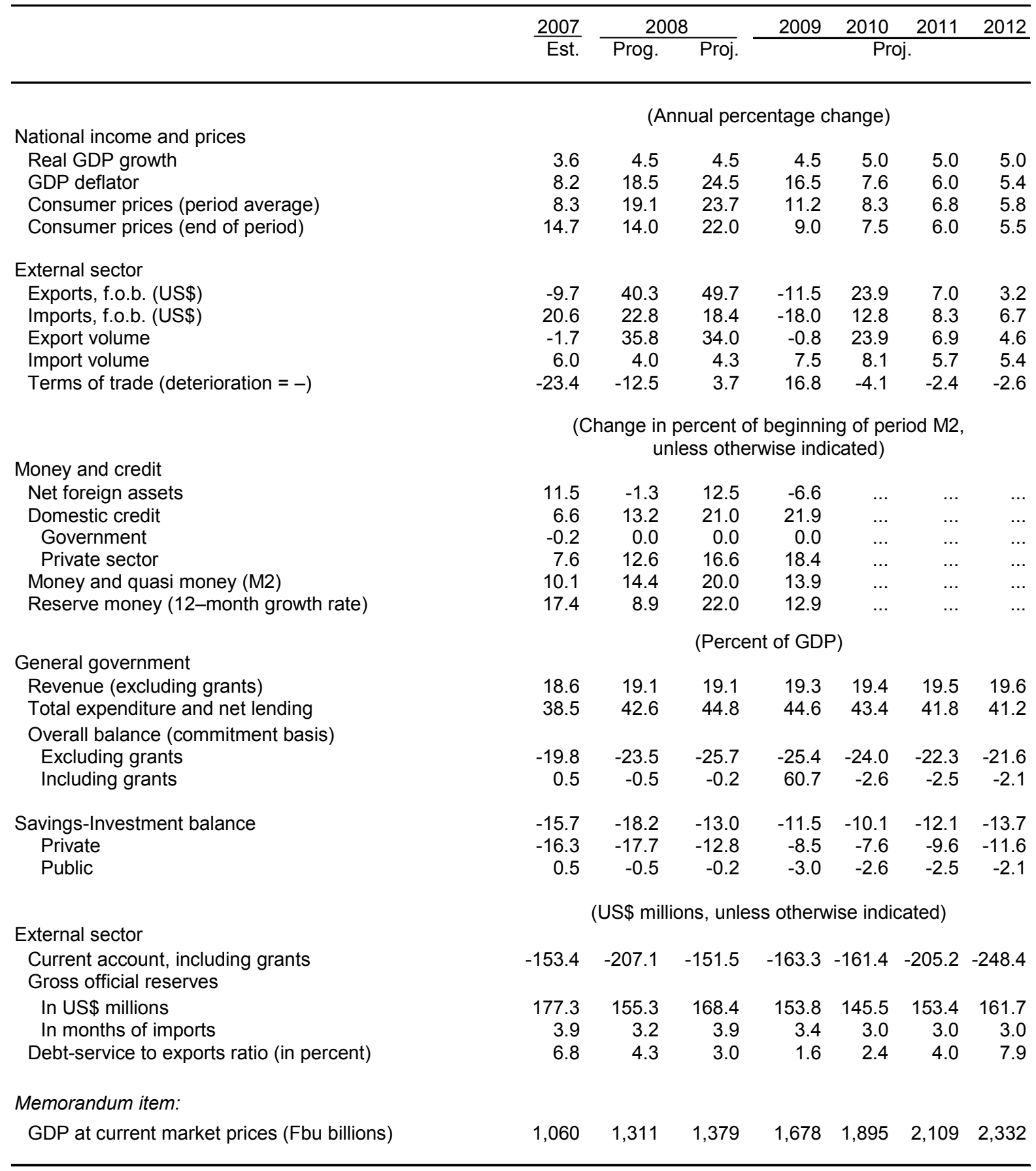

Sources: Burundi authorities; and IMF staff estimates and projections. 
Table 3. Burundi: General Government Operations, 2007-12

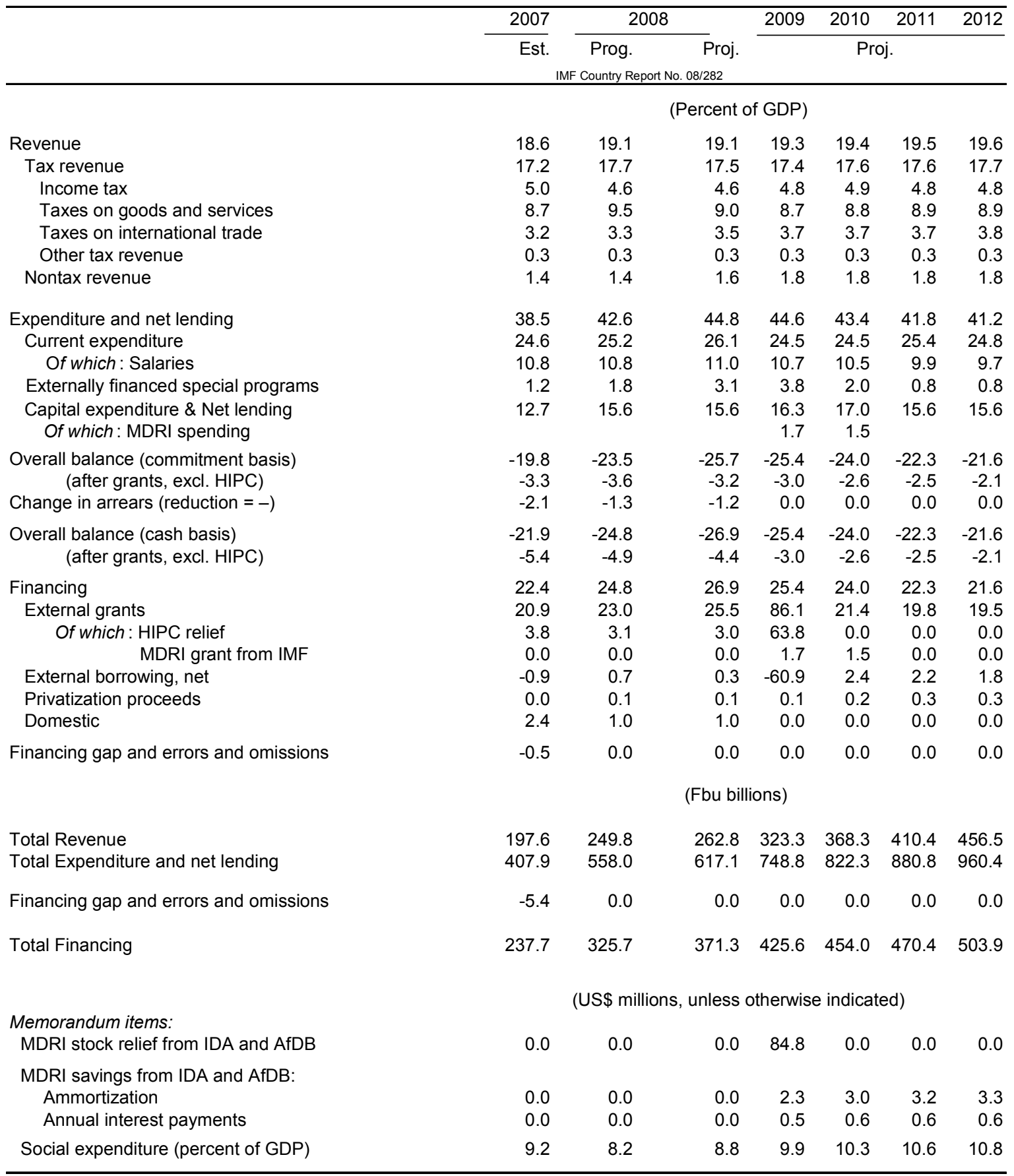

Sources: Burundi authorities; and IMF staff estimates and projections. 
Table 4. Burundi: Monetary Survey, 2005-09

\begin{tabular}{|c|c|c|c|c|c|c|}
\hline & 2005 & 2006 & 2007 & \multicolumn{2}{|c|}{2008} & 2009 \\
\hline & \multicolumn{3}{|c|}{ Actual } & Prog. & Proj. & Proj. \\
\hline & \multicolumn{6}{|c|}{ (Fbu billions) } \\
\hline Net foreign assets & 70.3 & 74.6 & 109.1 & 104.9 & 150.3 & 124.0 \\
\hline Central bank & 48.8 & 41.5 & 75.6 & 19.0 & 38.7 & 25.0 \\
\hline Deposit money banks & 21.5 & 33.1 & 33.5 & 85.9 & 111.5 & 98.9 \\
\hline Net domestic assets & 227.6 & 277.7 & 298.7 & 372.2 & 390.5 & 477.4 \\
\hline Domestic credit & 277.9 & 354.3 & 374.1 & 417.7 & 443.3 & 529.9 \\
\hline Net claims on the government & 121.1 & 158.1 & 157.4 & 157.4 & 157.4 & 157.3 \\
\hline Credit to the economy & 156.8 & 196.2 & 216.6 & 260.3 & 286.0 & 372.6 \\
\hline Other items, net (assets $=+$ ) & -50.4 & -76.6 & -75.4 & -45.6 & -52.9 & -52.5 \\
\hline M3 & 297.8 & 352.2 & 407.8 & 477.0 & 540.8 & 601.4 \\
\hline Foreign currency deposits & 40.2 & 52.3 & 77.7 & 99.4 & 144.5 & 150.0 \\
\hline M2 & 257.7 & 299.9 & 330.1 & 377.6 & 396.2 & 451.4 \\
\hline Currency in circulation & 67.9 & 68.4 & 84.2 & 98.4 & 117.6 & 135.2 \\
\hline Local currency deposits & 189.8 & 231.5 & 245.9 & 279.1 & 278.6 & 316.2 \\
\hline Demand deposits & 115.6 & 147.5 & 151.2 & 176.0 & 186.4 & 211.6 \\
\hline \multirow[t]{2}{*}{ Quasi-money } & 74.2 & 84.0 & 94.7 & 103.2 & 92.2 & 104.7 \\
\hline & \multicolumn{6}{|c|}{ (Change as percent of beginning of period M2) } \\
\hline Net foreign assets & 15.9 & 1.7 & 11.5 & -1.3 & 12.5 & -6.6 \\
\hline Central bank & 13.8 & -2.8 & 11.4 & -17.2 & -11.2 & -3.5 \\
\hline Deposit money banks & 2.1 & 4.5 & 0.1 & 15.9 & 23.6 & -3.2 \\
\hline Net domestic assets & 8.6 & 19.4 & 7.0 & 22.3 & 27.8 & 21.9 \\
\hline Domestic credit & -0.4 & 29.6 & 6.6 & 13.2 & 21.0 & 21.9 \\
\hline Net claims on the government & 7.2 & 14.4 & -0.2 & 0.0 & 0.0 & 0.0 \\
\hline Credit to the economy & -7.6 & 15.3 & 6.8 & 13.2 & 21.0 & 21.9 \\
\hline Of which: private sector & -6.7 & 13.7 & 7.6 & 12.6 & 16.6 & 18.4 \\
\hline Other items, net (assets $=+$ ) & 9.0 & 13.7 & 0.4 & 9.0 & 6.8 & 0.1 \\
\hline M3 & 24.5 & 21.1 & 18.5 & 21.0 & 40.3 & 15.3 \\
\hline Foreign currency deposits & -2.6 & 4.7 & 8.5 & 6.6 & 20.2 & 1.4 \\
\hline M2 & 27.1 & 16.4 & 10.1 & 14.4 & 20.0 & 13.9 \\
\hline Currency in circulation & 5.3 & 0.2 & 5.2 & 4.3 & 10.1 & 4.4 \\
\hline Local currency deposits & 21.8 & 16.2 & 4.8 & 10.1 & 9.9 & 9.5 \\
\hline Demand deposits & 7.7 & 12.4 & 1.2 & 7.5 & 10.7 & 6.4 \\
\hline Quasi-money & 14.1 & 3.8 & 3.6 & 2.6 & -0.8 & 3.1 \\
\hline \multicolumn{7}{|l|}{ Memorandum items: } \\
\hline Reserve money (12-month percent change) & 32.7 & 5.9 & 17.4 & 8.9 & 22.0 & 12.9 \\
\hline
\end{tabular}

Sources: Banque de la République du Burundi (BRB); and IMF staff estimates and projections. 
Table 5. Burundi: Central Bank Accounts, 2006-09

\begin{tabular}{|c|c|c|c|c|c|c|c|c|c|c|c|c|c|}
\hline & \multirow{3}{*}{$\begin{array}{l}2006 \\
\text { Dec. }\end{array}$} & \multicolumn{4}{|c|}{2007} & \multicolumn{4}{|c|}{2008} & \multicolumn{4}{|c|}{2009} \\
\hline & & \multirow[t]{2}{*}{ Mar. } & \multirow[t]{2}{*}{ Jun. } & \multirow[t]{2}{*}{ Sept. } & \multirow[t]{2}{*}{$\overline{\text { Dec. }}$} & \multirow[t]{2}{*}{ Mar. } & \multirow[t]{2}{*}{ Jun. } & \multirow[t]{2}{*}{ Sept. } & \multirow{2}{*}{$\begin{array}{l}\text { Dec. } \\
\text { Proj. }\end{array}$} & Mar. & Jun. & Sept. & Dec. \\
\hline & & & & & & & & & & \multicolumn{4}{|c|}{ Proj. } \\
\hline & \multicolumn{13}{|c|}{ (Fbu billions) } \\
\hline Net foreign assets & 41.5 & 30.9 & 17.8 & 5.8 & 75.6 & 69.9 & 63.4 & 75.1 & 38.7 & 18.3 & 12.4 & 13.0 & 25.0 \\
\hline Net domestic assets & 65.0 & 68.9 & 91.1 & 104.9 & 49.4 & 48.4 & 71.6 & 71.3 & 113.8 & 126.7 & 146.8 & 155.4 & 147.2 \\
\hline Domestic credit & 165.3 & 125.1 & 143.5 & 151.4 & 138.8 & 125.0 & 156.3 & 148.6 & 189.9 & 205.7 & 221.8 & 232.3 & 225.9 \\
\hline Net claims on the government & 161.4 & 120.4 & 140.3 & 148.1 & 134.7 & 121.6 & 150.7 & 143.1 & 133.1 & 130.1 & 127.1 & 124.1 & 121.3 \\
\hline Nongovernment credit & 3.9 & 4.7 & 4.6 & 3.0 & 3.2 & 3.4 & 5.6 & 5.4 & 56.8 & 75.6 & 94.6 & 108.2 & 104.5 \\
\hline Other items, net (assets $=+$ ) & -100.2 & -56.1 & -52.4 & -46.5 & -89.4 & -80.1 & -78.3 & -75.6 & -76.2 & -79.0 & -75.0 & -77.0 & -78.6 \\
\hline Reserve money & 106.5 & 99.8 & 108.9 & 110.8 & 125.0 & 118.3 & 135.1 & 146.5 & 152.5 & 145.0 & 159.2 & 168.4 & 172.3 \\
\hline Currency in circulation & 68.4 & 62.9 & 71.7 & 78.7 & 84.2 & 80.6 & 99.3 & 110.4 & 117.6 & 108.3 & 121.9 & 129.0 & 135.2 \\
\hline Bank reserves & 28.2 & 26.6 & 27.5 & 21.8 & 24.9 & 23.5 & 18.9 & 17.3 & 16.1 & 17.9 & 18.5 & 20.7 & 18.3 \\
\hline Cash in vault & 8.4 & 7.7 & 7.9 & 8.0 & 8.8 & 9.1 & 9.9 & 12.6 & 12.6 & 12.6 & 12.6 & 12.6 & 12.6 \\
\hline Other nonbank deposits & 1.4 & 2.6 & 1.8 & 2.2 & 7.1 & 5.1 & 7.1 & 6.2 & 6.2 & 6.2 & 6.2 & 6.2 & 6.2 \\
\hline \multicolumn{14}{|l|}{ Memorandum items: } \\
\hline NFA of BRB (US\$ millions) & 41.4 & 29.6 & 16.3 & 5.2 & 67.5 & 59.3 & 53.1 & 63.3 & 33.3 & 15.4 & 10.4 & 11.0 & 21.6 \\
\hline
\end{tabular}

Sources: Banque de la République du Burundi (BRB); and IMF staff estimates and projections. 
Table 6. Burundi: Balance of Payments, 2007-12

\begin{tabular}{|c|c|c|c|c|c|c|}
\hline & & 2008 & 2009 & 2010 & 2011 & 2012 \\
\hline & Est. & Proj. & \multicolumn{4}{|c|}{ Proj. } \\
\hline & \multicolumn{6}{|c|}{ (US\$ millions) } \\
\hline $\begin{array}{l}\text { Current account } \\
\text { (excluding official transfers ) }\end{array}$ & $\begin{array}{l}-153.4 \\
-364.4\end{array}$ & $\begin{array}{l}-151.5 \\
-395.6\end{array}$ & $\begin{array}{l}-163.3 \\
-365.6\end{array}$ & $\begin{array}{l}-161.4 \\
-376.8\end{array}$ & $\begin{array}{l}-205.2 \\
-400.2\end{array}$ & $\begin{array}{l}-248.4 \\
-421.4\end{array}$ \\
\hline Trade balance & -242.0 & -269.9 & -216.3 & -236.1 & -257.0 & -277.4 \\
\hline Exports, f.o.b. & 52.9 & 79.2 & 70.1 & 86.9 & 92.9 & 95.8 \\
\hline Of which: coffee & 32.6 & 52.6 & 44.5 & 60.0 & 64.6 & 66.1 \\
\hline Imports, f.o.b. & -295.0 & -349.2 & -286.4 & -323.0 & -349.9 & -373.2 \\
\hline Of which: petroleum products & -58.4 & -108.1 & -81.1 & -98.4 & -112.3 & -125.7 \\
\hline Services (net) & -145.6 & -159.1 & -189.0 & -181.6 & -186.0 & -188.1 \\
\hline Income (net) & -5.9 & -4.4 & -6.2 & -7.5 & -7.8 & -9.2 \\
\hline Current transfers (net) & 240.1 & 281.9 & 248.2 & 263.7 & 245.6 & 226.2 \\
\hline of which: official (net) & 211.0 & 244.1 & 202.2 & 215.5 & 195.0 & 173.0 \\
\hline Capital account & 127.4 & 145.0 & 1245.9 & 143.3 & 150.3 & 161.3 \\
\hline Of which: HIPC relief & 39.4 & 39.7 & 0.0 & 0.0 & 0.0 & 0.0 \\
\hline Debt forgiveness & & & 1068.6 & & & \\
\hline Other transfers (MDRI grant) & 0.0 & 0.0 & 51.0 & 0.0 & 0.0 & 0.0 \\
\hline Financial account & 84.6 & -6.3 & -1097.1 & 9.8 & 62.8 & 95.4 \\
\hline Direct investment & 0.5 & 0.5 & 0.5 & 0.8 & 1.3 & 1.8 \\
\hline Other investment & 84.1 & -6.8 & -1097.6 & 9.0 & 61.5 & 93.6 \\
\hline Assets & -45.0 & -117.6 & 4.3 & -42.5 & -41.2 & -40.1 \\
\hline Liabilities & 129.1 & 110.8 & -1101.9 & 51.5 & 102.8 & 133.7 \\
\hline Errors and omissions & -29.6 & 0.0 & 0.0 & 0.0 & 0.0 & 0.0 \\
\hline Overall balance & 29.0 & -12.8 & -14.6 & -8.3 & 7.9 & 8.3 \\
\hline Financing (increase in assets $=-$ ) & -29.0 & 12.8 & 14.6 & 8.3 & -7.9 & -8.3 \\
\hline Of which: Net change in official reserves & -46.2 & 8.9 & 14.6 & 8.3 & -7.9 & -8.3 \\
\hline \multirow[t]{2}{*}{ Financing gap } & 0.0 & 0.0 & 0.0 & 0.0 & 0.0 & 0.0 \\
\hline & \multicolumn{6}{|c|}{ (Percent of GDP, unless otherwise indicated) } \\
\hline \multicolumn{7}{|l|}{ Memorandum items: } \\
\hline Current account & -15.7 & -13.0 & -11.5 & -10.1 & -12.1 & -13.7 \\
\hline \multicolumn{7}{|l|}{ Gross official reserves } \\
\hline In US\$ millions & 177.3 & 168.4 & 153.8 & 145.5 & 153.4 & 161.7 \\
\hline In months of exports & 3.9 & 3.9 & 3.4 & 3.0 & 3.0 & 3.0 \\
\hline Nominal GDP (US\$ millions) & 975 & 1170 & 1416 & 1593 & 1694 & 1808 \\
\hline
\end{tabular}

Sources: Burundi authorities; and IMF staff estimates and projections. 
Table 7. Burundi: Actual and Projected Schedule of PRGF Disbursements and Reviews, 2008-11

\begin{tabular}{lcl}
\hline \multicolumn{1}{c}{ Date } & $\begin{array}{c}\text { Disbursement } \\
\text { (SDR millions) }\end{array}$ & \multicolumn{1}{c}{ Conditions } \\
\hline July 15, 2008 & 6.6 & $\begin{array}{l}\text { Executive Board approval } \\
\text { Completion of first review, based on } \\
\text { observance of performance criteria at } \\
\text { end-September 2008. }\end{array}$ \\
January 15, 2009 & 6.6 & $\begin{array}{l}\text { Completion of second review, based on } \\
\text { observance of performance criteria at } \\
\text { end-March 2009. }\end{array}$ \\
July 6, 2009 & 6.6 & $\begin{array}{l}\text { Completion of third review, based on } \\
\text { observance of performance criteria at } \\
\text { end-September 2009. }\end{array}$ \\
July 6, 2010 & 6.6 & $\begin{array}{l}\text { Completion of fourth review, based on } \\
\text { observance of performance criteria at } \\
\text { end-March 2010. }\end{array}$ \\
January 15, 2011 & 6.6 & $\begin{array}{l}\text { Completion of fifth review, based on } \\
\text { observance of performance criteria at } \\
\text { end-September 2010. }\end{array}$ \\
July 6, 2011 & 6.6 & $\begin{array}{l}\text { Completion of sixth review, based on } \\
\text { observance of performance criteria at } \\
\text { end-March 2011. }\end{array}$ \\
\hline
\end{tabular}


Table 8. Burundi: Banking System Soundness Indicators, 2005-08 (in percent, unless otherwise indicated)

\begin{tabular}{|c|c|c|c|c|}
\hline & Dec-05 & Dec-06 & Dec-07 & Sep-08 \\
\hline \multicolumn{5}{|l|}{ Capital Requirement } \\
\hline Capital requirement over weighted assets (solvency ratio) & 17.0 & 13.2 & 13.5 & 14.1 \\
\hline Core capital (Tier 1 capital) over weighted assets ${ }^{1}$ & 16.5 & 7.6 & 10.9 & 11.0 \\
\hline Capital over assets & 8.9 & 8.9 & 8.5 & 9.5 \\
\hline \multicolumn{5}{|l|}{ Quality of assets } \\
\hline Nonperforming loans (percent of total gross loans granted) & 20.6 & 18.6 & 18.8 & 17.9 \\
\hline Provisions (percent of nonperforming loans) & 81.7 & 90.2 & 92.6 & 92.9 \\
\hline Nonperforming loans net of provisions (percent of capital) & 20.4 & 25.5 & 7.4 & 10.1 \\
\hline Large exposures (percent of capital) & 34.3 & 47.7 & 41.6 & 53.7 \\
\hline \multicolumn{5}{|l|}{ Profitability rates } \\
\hline Return on assets & 1.9 & 1.7 & 2.3 & 2.4 \\
\hline Return on equity capital & 14.1 & 17.5 & 26.4 & 25.5 \\
\hline Net interest (percent of gross results) & 180.5 & 177.4 & 167.6 & 158.6 \\
\hline Costs excluding interest (percent of gross outturn) & 175.7 & 188.9 & 156.6 & 129.0 \\
\hline Payroll expenses (percent of charges excluding interest) & 25.8 & 23.2 & 24.9 & 28.0 \\
\hline \multicolumn{5}{|l|}{ Liquidity } \\
\hline Liquid assets (percent of total assets) & 34.0 & 33.1 & 38.1 & 33.4 \\
\hline Liquid assets (percent of short-term commitments) & 87.0 & 106.8 & 135.2 & 109.5 \\
\hline Customer deposits (percent of all loans granted) & 132.6 & 134.8 & 148.5 & 116.0 \\
\hline
\end{tabular}

Source: Burundi authorities.

${ }^{1}$ The decrease is due to the revision of Article 2 in Directive No. $2 / 06$ of November 24, 2006. It is related to the calculation of basic equity capital, which no longer includes general provisions for risks. 


\section{Appendix I. Burundi: Letter of Intent}

Bujumbura, January 8, 2009

Dominique Strauss-Kahn

Managing Director

International Monetary Fund

Washington, D.C., 20431

Dear Mr. Strauss-Kahn,

1. The Executive Board of the International Monetary Fund (IMF) approved a three-year arrangement for Burundi on July 7, 2008, under the Poverty Reduction and Growth Facility (PRGF). This arrangement supports the medium-term program (from April 1, 2008 to March 31,2011 ) aimed at continuing the process of macroeconomic stabilization, reducing poverty, promoting structural reforms, and enhancing governance. In accordance with this arrangement, the government of Burundi carried out the first review of the program together with a mission from the IMF. This review focused on implementation of the program during the period from April 1, 2008 to September 30, 2008, as well as the prospects and economic and financial measures to be implemented in 2009.

2. On the political front, the government of Burundi continues to make every effort to consolidate the peace process by implementing the agreements signed between Burundi and the warring parties.

3. On the economic and social front, the government of Burundi is pleased to report that implementation of the program has been satisfactory during the first six months of its application, despite the difficult international situation caused largely by the substantial increase in world food and oil prices. In particular, all the quantitative and structural performance criteria have been met as of September 2008.

4. The government of Burundi hopes that its strong desire and determination to implement its program rigorously with the support of the PRGF will open the way for Burundi to move toward the HIPC Initiative completion point, which we expect to reach no later than end-January 2009.

5. The government is resolved to continue implementing the policies and measures described in the Poverty Reduction Strategy Paper (PRSP) published in September 2006 and the findings of the final report sent to the IMF and the World Bank in November 2008. The Memorandum on Economic and Financial Policies (MEFP) attached to this letter completes the memorandum dated June 24, 2008. 
6. The government believes that the policies set forth in the attached Memorandum of Economic and Financial Policies (MEFP) are adequate to achieve the objectives of its program, but it will take any further measures that may become appropriate for this purpose. Burundi will consult with the Fund on the adoption of these measures, and in advance of revisions to the policies contained in the MEFP, in accordance with the Fund's policies on such consultation.

7. The government of Burundi will provide the IMF with such information as it may request in connection with monitoring the progress made in economic and financial policy implementation. Burundi will also carry out reviews of the PRGF-supported program with the IMF every six months. The second review conducted with the IMF should be completed no later than July 2009 and the third review no later than January 2010.

8. In view of the considerable progress achieved in implementing the program supported by the PRGF, the government is requesting completion of the first review and the second disbursement of SDR 6.6 million under the PRGF.

9. As in the past, the Burundi authorities wish to make this letter available to the public, along with the attached MEFP and technical memorandum of understanding (TMU), as well as the IMF staff reports on the first PRGF review and the HIPC Initiative completion point. We, therefore, authorize their publication and posting on the IMF website, subject to Executive Board approval. These documents will also be posted on the official websites of the Burundi government.

Sincerely yours,

$/ \mathrm{s} /$

Clotilde NIZIGAMA

Minister of Economy, Finance, and

Cooperation for Development

Republic of Burundi
$/ \mathrm{s} /$

Gaspard SINDAYIGAYA

Governor, Bank of the

Republic of Burundi

$/ \mathrm{s} /$

Gabriel NTISEZERANA

Second Vice-President, Republic of Burundi

Attachments: Memorandum on Economic and Financial Policies

Technical Memorandum of Understanding 


\section{Attachment I. Burundi: Memorandum on Economic and Financial Policies}

\section{INTRODUCTION}

1. This Memorandum on Economic and Financial Policies (MEFP) completes the memorandum dated June 24, 2008. It provides an update on the medium-term prospects of government action, reports on program implementation in 2008, and presents the economic and financial policy that will be implemented in 2009 within the framework of the program covering the period from April 1, 2008 to March 31, 2011. The measures and objectives contained in this MEFP are compatible with the Poverty Reduction Strategy Paper (PRSP) published in September 2006 and the findings of the final report sent to the IMF and the World Bank in November 2008.

2. Economic policy will continue to be guided by the following objectives: (1) return to single-digit inflation; (2) improve the composition of public spending to the benefit of priority sectors while preserving budget sustainability; (3) strengthen fiscal management (FM) and good governance; and (4) strengthen the internal control systems of the central bank.

3. Provided that public security continues to improve, the macroeconomic objectives are as follows for the period of the PRGF-supported program: (1) GDP growth should average 5 percent over the medium term, compared to the 2004-07 level of 3.6 percent; (2) inflation should slow to about 6 percent in 2011; and (3) gross official reserves should stabilize at coverage of about three months of imports.

\section{Program Implementation in 2008}

4. Macroeconomic developments have been generally in line with the program, even if inflation was slightly higher than anticipated. For 2008, real GDP growth is projected to remain at 4.5 percent, owing to a good coffee harvest. Inflation is expected to be 22 percent compared to the targeted 14 percent as a result of the increase in world food and oil prices. The overall budget deficit should be at the programmed level, and Burundi's external position will also be in line with program objectives.

5. All the quantitative performance criteria as of end-September 2008 have largely been met. On the other hand, the target for cumulative internal arrears was not met because of the delay in disbursements of budget support. Moreover, the payroll ceiling was exceeded as a result of higher-than-expected payrolls in the priority sectors.

6. The government has made significant progress in structural reforms. With respect to fiscal management, the parliament adopted a new budget Organic Law that takes into account modern principles of fiscal management and transparency and specifies the concepts, 
principles, and responsibilities applicable to staff of the public revenue department. The action plan aimed at replacing the transaction tax with the value-added tax was approved by the Council of Ministers. The elimination of all exemptions in the indirect tax system is to be incorporated into the new tax code, which is expected to be adopted in 2009. The government also completed the census of government civil servants. The report indicates that the civil servant status of 1,801 agents remains to be verified. The census of police and armed forces personnel has been started.

7. In the economic and financial area, the new investment law promulgated in September 2008 is consistent with best international practices and is aimed at improving the business climate. The parliament also adopted a new law concerning the central bank that reinforces its independence and good governance, in accordance with best international practices. Moreover, the central bank has implemented important measures to strengthen its system of internal controls and risk management, following the recommendations of the recent safeguards assessment report prepared by IMF staff.

8. To deal with the increase in world food prices that has dealt a hard blow to our country, the government has taken a number of measures aimed at helping the vulnerable groups of society while encouraging local production. Temporary and targeted tariff reductions have been carried out on food and oil imports consumed by the poor. In order to reduce the social impact of the food crisis, the government has reinforced the social safety nets, particularly for programs involving food security, school cafeterias, transfers to farmers, rural agricultural micro credits, and assistance to refugees displaced by the war. Finally, to increase agricultural production, the government has provided citizens with seeds and fertilizer and launched programs to rehabilitate the irrigation system in the Imbo plain and basic infrastructure. The government would like to thank all the donors that have financially supported these initiatives, particularly the World Bank, the Netherlands, Norway, the European Union, and the African Development Bank.

\section{ECONOMic Prospects ANd Policies for 2009}

\section{A. Budget Policy}

9. The macroeconomic framework for the 2009 budget is as follows: (1) GDP growth should remain at 4.5 percent; (2) end-of-period inflation should fall to 9 percent; and (3) gross official reserves should stabilize at coverage of about $3 \frac{1}{2}$ months of imports.

10. It is crucial to mobilize sufficient inland revenue to ensure the viability of the budget and increase expenditure for poverty reduction. The government will maintain the tax burden at about 19 percent of GDP, the level projected for 2008. Although introduction of the VAT and adoption of the common external tariff (CET) of the East African Community (EAC) could have a positive impact on revenue over the medium term, studies show that they could 
result in a loss of revenue amounting to about 0.4 percent of GDP in 2009. The government has asked the IMF for the assistance of a resident expert to help facilitate the introduction of this major fiscal reform.

11. To ensure that the revenue target is met, important measures involving fiscal and administrative policy will be taken. In particular, the government will gradually eliminate in 2009 the temporary suspension of tax levies on oil products, while taking into account the social impact on the poor. The general tax base will also be expanded by (i) reducing exemptions; (ii) continuing the census of all taxpayers, including the informal sector; and (iii) collecting tax on the remuneration of the local personnel of international agencies. Other measures, such as the renewal of auto license plates and recovery of arrears, will also help achieve the revenue target. The creation in January 2009 of the Revenue Office is a major reform that will help increase government revenue in the medium term.

12. The primary objective of the 2009 expenditure policy is to improve significantly the composition of public spending in favor of priority sectors in order to accelerate progress toward achieving the Millennium Goals. Priority expenditures are projected to increase by about 1 percent of GDP, despite the decrease in budget support in 2009. In the health sector, the necessary funds have been budgeted to provide free health care to children under 5 and to women at the time of childbirth. Plans also include recruiting 609 health care workers, including 50 physicians. In order to improve health care coverage in Burundi, a policy will be adopted to construct 10 new health centers in the most underprivileged regions.

13. In the area of education, increased funds will be dedicated to the infrastructure of schools, recruiting of teachers, and teaching materials, in order to respond to the needs of the school system stimulated by providing free primary education. The government also plans to build 1,183 classrooms at the primary level and 289 classrooms at the secondary level. The government plans to recruit 3,667 teachers, including 2,567 at the primary level, which will help lower the teacher-student ratio.

14. In the agricultural sector, efforts will be made to intensify food production in order to ensure food security. The savings from debt relief within the framework of the Multilateral Debt Relief Initiative (MDRI) will be dedicated to improving the hydraulic infrastructure, in particular the rehabilitation and extension of the irrigation system in the Imbo plain. A largescale program for planting fruit trees will be continued, in view of the spectacular results obtained to date. In addition to its direct impact on the environment, this program will have positive effects on poverty by generating substantial revenue in rural zones and helping to reintegrate ex-combatants into society.

15. With respect to the government payroll, the target remains bringing the ratio of payroll to GDP to under 10 percent near the end of the program in 2011. To control wages, 
the government will continue to draw on the findings of the Public Expenditure Management and Financial Accountability Review (PEMFAR) prepared jointly by the World Bank and the government of Burundi. In particular, with the completion of the census of civil servants, the government will take measures to eliminate any ghost employees if it is ascertained that they exist. The government will continue to take the following measures in 2009: (1) freeze partially the recruitment of civil servants, except in the sectors of health, education, agriculture, and justice; (2) only partially replace retirees with new wage earners; (3) centralize recruitment by strengthening the powers of the recruitment commission; and (4) complete the census of staff in the police and armed forces in the first half of 2009. In addition, the finance ministry should assume responsibility for payroll management by taking over the corresponding database not later than end-March 2009 ( end-March 2009 structural performance criterion).

16. In order to establish a coherent framework for wage increases that takes budget resources into account, the government will conduct an audit to evaluate the budgetary impact of its past commitments for salary adjustments that have not yet been applied. Based on this audit, the government will seek an agreement with the social partners for commitments already made, while taking into account the budgetary framework. Salaries have eroded in real terms over the past years, and today the average monthly salary of a civil servant is less than $\$ 75$.

17. With respect to demobilization and reintegration policies, the government will continue to cooperate with the World Bank and other donors to ensure that this policy is carried out in a manner that effectively reintegrates ex-combatants into society and improves security conditions. With a return to peace, the reduction in military and security spending will leave a little more room for budget flexibility, as needed to increase poverty reduction expenditure without endangering budget sustainability.

18. In view of the food crisis that continues to affect the poor and most vulnerable sectors of society, the government will request donors to continue the budget support granted in 2008 to help adjust to this shock and reduce its impact on the poor. Urgent expenditure for social safety nets, amounting to about US\$9 million (about 0.6 percent of GDP) will be possible if additional budget support is obtained. This amount will make it possible to maintain the social safety nets and targeted assistance for the most vulnerable and farmers. The contributions of donors will also be necessary for school cafeteria programs in the most vulnerable areas and for the distribution of agricultural inputs to small farmers. In order to increase agricultural production, the government is working with donors (particularly the World Bank and FAO) to develop rural infrastructure, diversify agricultural production, and enhance agricultural productivity through research programs and irrigation systems. 
19. To support the budget policy, the government will prepare and implement a sliding quarterly cash-flow plan (structural benchmark end-June 2009). All budget spending will require the prior authorization of the finance minister and will be executed strictly on the basis of revenue availability. A monthly budget allocation for each ministry should be defined with strict expenditure prioritization. To protect priority spending, the government will identify in advance nonpriority expenditure that will be cut in the event of a decline in revenue or financing.

\section{B. Monetary and Foreign Exchange Policy}

20. The government plans to pursue a prudent monetary policy, which is necessary to limit inflationary expectations. Until the objective of single-digit inflation is attained, the central bank will set the broad money growth rate below the nominal GDP growth rate. Such

prudent monetary policy will help prevent the second-round price effect of commodity prices and other supply shocks.

21. The overall financing provided by the central bank to the government will be zero in 2009. With respect to advances from previous years (2006 and 2007), the finance minister and the central bank will negotiate a new agreement on reimbursement of these advances.

22. Better budget and monetary policy coordination will be essential, especially during this period of increasing inflationary pressures. In this regard, the computerized system for exchanging data between the finance ministry and the central bank will be put into operation.

23. Proactive management of foreign exchange reserves and sterilization of foreign exchange operations will continue within a managed floating exchange rate regime, with a view to achieving the inflation target. With technical assistance from the IMF, the central bank will continue to implement the recommendations of the IMF experts for improving the function of the foreign exchange market.

\section{Structural Reforms}

24. In close collaboration with development partners, the government will continue pursuing ongoing structural reforms: promotion of transparency and good governance, financial sector reform, regional integration; coffee sector reform, and oil sector reform.

\section{Fiscal management}

25. On the basis of various technical assistance reports (including the PEMFAR), the government will implement a strategy and action plan for fiscal management reforms. By end-September 2009, the Council of Ministers will adopt the fiscal management strategy and 
action plan, and the relevant ministries will authorize establishment of the entities responsible for their implementation.

26. In order to facilitate the gradual implementation of the single Treasury account, the government's bank accounts are being rationalized. In this context, the government has merged the ordinary budget with the investment budget and has closed more than 90 ministerial accounts. Drawing lessons from this experience, the government is committed to continuing the task of rationalizing its accounts without compromising the functions of the departments concerned. This operation should also provide the finance minister with a certain degree of flexibility. To this end, the off-budget accounts mentioned in the finance minister's letter no. 540/4904/2008 of November 12, 2008, will gradually be closed and transformed into subaccounts for special allocation from the general treasury account, no later than September 30, 2009 (end-September 2009 structural performance criterion). The government will also continue rationalizing ministerial and other accounts by closing the accounts mentioned in the finance minister's letter no. 540/4768/2008 of October 31, 2008 (endSeptember 2009 structural performance criterion).

27. With the promulgation of the new budget organic law in 2009 , the government will make efforts to implement it gradually. In this context, the new general regulations on fiscal affairs will complete the renovation of the legislative and regulatory framework. In order to optimize budget execution procedures, the finance minister will prepare the budget procedures manual and implement a revised list of supporting documents. In order to enhance the reform of budget and general government accounting, a new accounting procedures manual will be prepared and the accounts classification will be aligned with the budget classification.

\section{Promoting good governance}

28. The fiscal management and central bank reforms mentioned will be decisive. In addition, to accelerate the resolution of pending cases involving the embezzlement of public funds, the government will dedicate more resources (financial, material, and human) to the justice and anticorruption agencies (the State General Inspectorate, the special anticorruption team, the public prosecutor's office at the anticorruption court, and the anticorruption court). Given the immensity of the task to be accomplished by these agencies, the government is launching an appeal to development partners to provide financial and technical support to these new entities. Based on the results of the survey on corruption in Burundi conducted by the World Bank, the government will adopt a detailed anticorruption strategy in 2009.

29. With respect to the governance issues related to INTERPETROL, the authorities are committed to pursuing the legal procedures related to this case. In accordance with the laws of Burundi, the Fbu 6 billion and the deeds for 25 properties belonging to INTERPETROL that have been placed under seal will remain in place until a court decision has been reached 
on the case (continuous performance criterion). With respect to the tax arrears of the oil sector, the government will accelerate their collection by all legal means, based on the report on the audit of the cross-debts between the government and the oil sector.

\section{Financial sector}

30. With the promulgation of the new law on the central bank charter, the central bank will develop an action plan, with deadlines, for implementing the law and will continue to take measures to strengthen its internal control and risk management systems, following the recommendations of the technical assistance on the internal audit and the recent safeguards assessment report prepared by IMF staff. The central bank will submit to the General Council, the audit committee, and the finance minister the report on the special audits of the controls on major domestic disbursements and transfers - on behalf of the government or its creditors - that took place in the first half of 2008 (prior action). The central bank is also committed to recruiting an international auditor to conduct special audits of those controls that took place in the second half of 2008 (prior action).

31. To reinforce the financial sector, the central bank will continue taking measures to restructure certain banks. In the wake of the international financial crisis, the central bank is enhancing banking supervision. In particular, measures will be taken to implement the recommendations of the technical assistance on banking supervision. The self-evaluation of compliance with the 25 Basel principles resulted in a number of recommendations that the central bank is committed to implementing as rapidly as possible. In addition, the study on the financial sector planned for January 2009 will guide the central bank in adopting its strategy and action plan for reform of the financial sector.

\section{Regional and commercial integration}

32. Progress in the area of commercial integration is key for achieving medium-term growth objectives, and Burundi stands to benefit considerably from joining the EAC. Aware of these potential advantages, the government has already established an interministerial committee to coordinate government efforts and facilitate the decision-making process. A national strategy and action plan, prepared with the assistance of the development partners, will be adopted soon.

\section{Coffee sector reform}

33. The reforms of the coffee sector are of great macroeconomic importance. This sector is the principal source of income for nearly 800,000 Burundi households, and coffee accounts for about two-thirds of total exports. In order to reform this sector, the government has adopted new regulations on sales, opening the coffee export market to local and international actors. The implementation of these regulations has resulted in effective penetration by exporters based on the principles of competition and transparency. In collaboration with the 
World Bank, the government in December 2008 adopted a plan for the withdrawal of state from the coffee sector.

\section{Oil sector reform}

34. In collaboration with the World Bank, a study of the sector is currently being conducted. The government will request technical assistance from the IMF's Fiscal Affairs Department on the use of fiscal policies and public expenditure to better protect the poor, within the framework of an automatic price adjustment mechanism.

\section{External Financing}

35. The government will ensure that all its external obligations are settled when due. The minister of finance prepares monthly public debt position reports that give a detailed survey of obligations falling due. These reports, which will continue to be published each month (a completion point trigger for the HIPC Initiative), will thus be a factor for strengthening Burundi's debt management.

36. Burundi will seek only concessional external financing or grants. The government will not contract nonconcessional foreign debt and will ensure that all loans contracted have a grant element of at least 50 percent. To ensure that the concessionality threshold is respected, the government will ensure compliance with the provision that the minister of finance has the exclusive right to negotiate and ratify external loans.

37. The government hopes to obtain debt relief under the HIPC Initiative and the MDRI by end-January 2009 at the latest and will pursue negotiations with its non-Paris Club bilateral creditors to obtain debt relief from them on terms similar to those granted by Paris Club bilateral creditors.

\section{E. Technical Assistance and Coordination of Development Partners}

38. Burundi has vast technical assistance needs. The authorities plan to remain in close collaboration with bilateral and multilateral partners to build up the administrative capacity of the country's institutions. The maintenance of IMF technical assistance, in particular through the AFRITAC, remains key in the areas of tax policy and administration, public expenditure management, monetary and foreign exchange policy, banking supervision, and economic statistics.

39. It is essential to coordinate relations with development partners (DPs), considering that they finance a major portion of budget expenditure. The government has intensified its efforts to set up an institutional framework for coordination of assistance in the form of the National Assistance Coordination Committee (CNCA). This initiative is supported financially by the DPs. The CNCA can help: 
- $\quad$ Organize the work between the government and the DPs at the sectoral level, relying on a lead donor among the DPs for each sector. A major priority should be the creation of sectoral groups, as described in the CNCA organizational chart.

- $\quad$ Centralize coordination of assistance within a single agency, which would facilitate coordination and decision-making by the government.

- Monitor aid disbursement and project implementation, in close collaboration with the minister of finance, to ensure that all financial assistance from the DPs is included in the budget.

\section{F. Program Monitoring}

40. The government will implement the measures shown in Table 2 before completion of the first review of the PRGF arrangement.

41. Program implementation will be monitored on the basis of half-yearly reviews of performance criteria, performance indicators, and structural benchmarks, as shown in Tables 4 and 5. The information to be reported to the IMF and the definitions of the pertinent variables can be found in the attached TMU. Program implementation, achievement of related objectives, and compliance with the performance criteria will be the subject of two half-yearly reviews. The authorities also stand ready to adopt, in consultation with IMF staff, any further financial or structural measures that may prove necessary for the success of the program. 
Table 1. Republic of Burundi: Performance Criteria and Structural Benchmarks for 2008

\begin{tabular}{|c|c|c|c|}
\hline Measures & $\begin{array}{l}\text { Condition Type } \\
\text { and Date }\end{array}$ & Status & $\begin{array}{l}\text { Macroeconomic } \\
\text { Rationale }\end{array}$ \\
\hline \multicolumn{4}{|l|}{ Fiscal management } \\
\hline $\begin{array}{l}\text { Completion of the census of all } \\
\text { government civil employees. }\end{array}$ & $\begin{array}{l}\text { Performance criterion } \\
\text { (September } 30,2008)\end{array}$ & Completed & $\begin{array}{l}\text { To reinforce wage bill } \\
\text { management through the }\end{array}$ \\
\hline Start of the police and army census. & $\begin{array}{l}\text { Structural benchmark } \\
\text { (October } 31,2008)\end{array}$ & $\begin{array}{l}\text { Completed. The } \\
\text { physical police } \\
\text { census has } \\
\text { begun and the } \\
\text { military census } \\
\text { has been } \\
\text { launched. }\end{array}$ & $\begin{array}{l}\text { creation of a single wage } \\
\text { data management and } \\
\text { elimination of ghost } \\
\text { employees. }\end{array}$ \\
\hline \multicolumn{4}{|l|}{ Revenue administration and tax policy } \\
\hline $\begin{array}{l}\text { Approval by the Council of Ministers of an } \\
\text { action plan to replace the transaction tax } \\
\text { with VAT. }\end{array}$ & $\begin{array}{l}\text { Structural benchmark } \\
\text { (July } 30,2008)\end{array}$ & $\begin{array}{l}\text { Completed with a } \\
\text { slight delay. }\end{array}$ & $\begin{array}{l}\text { To raise efficiency of tax } \\
\text { collection, and offset } \\
\text { potential losses on } \\
\text { customs revenue due to } \\
\text { the accession to EAC. }\end{array}$ \\
\hline $\begin{array}{l}\text { Elimination of all indirect tax exemptions } \\
\text { and maintenance of the time limit on } \\
\text { investment code exemptions. }\end{array}$ & $\begin{array}{l}\text { Structural benchmark } \\
\text { (September 30, 2008) }\end{array}$ & $\begin{array}{l}\text { Completed with a } \\
\text { delay of one day; } \\
\text { the investment } \\
\text { code has been } \\
\text { adopted. }\end{array}$ & $\begin{array}{l}\text { To improve fiscal stance } \\
\text { by reducing tax } \\
\text { exemptions and enhancing } \\
\text { controls on exemptions } \\
\text { stipulated in the } \\
\text { investment code. }\end{array}$ \\
\hline \multicolumn{4}{|l|}{ Fiscal governance } \\
\hline $\begin{array}{l}\text { FBu } 6 \text { billion taken as security and the } \\
\text { deeds for } 25 \text { properties belonging to } \\
\text { INTERPETROL placed under seal, as } \\
\text { required under the Burundi law, to remain } \\
\text { in place in compliance with such law until a } \\
\text { court makes a ruling on the } \\
\text { INTERPETROL legal proceedings. }\end{array}$ & $\begin{array}{l}\text { Performance criterion } \\
\text { (continuous) }\end{array}$ & Completed & $\begin{array}{l}\text { Enhance fiscal governance } \\
\text { to ensure the continuation } \\
\text { of budget support. }\end{array}$ \\
\hline
\end{tabular}


Table 2. Republic of Burundi: Prior Actions Before the Executive Board's Consideration of the First Review of the PRGF-Supported Program

\begin{tabular}{lll}
\hline \multicolumn{1}{c}{ Measures } & Status & Macroeconomic Rationale \\
\hline $\begin{array}{l}\text { Central Bank-Safeguard Measures } \\
\text { Submit to the General Council, the audit } \\
\text { committee, and the finance minister the } \\
\text { report on the special audits of the controls on } \\
\text { important domestic disbursements and } \\
\text { transfers-on behalf of the government or its } \\
\text { creditors-that took place in the first half of }\end{array}$ & Done & $\begin{array}{l}\text { Enhance the safeguard measures } \\
\text { in force at the central bank. }\end{array}$ \\
$\begin{array}{l}2008 . \\
\text { Recruit an international auditor to conduct } \\
\text { special audits of the controls on important } \\
\text { domestic disbursements and transfers-on } \\
\text { behalf of the government or its creditors- } \\
\text { that took place in the second half of } 2008 .\end{array}$ & Done & Enhance the safeguard measures \\
& & \\
\end{tabular}


Table 3: Burundi: Performance Criteria and Indicative Targets for 2008

(Fbu billions, unless otherwise indicated)

\begin{tabular}{|c|c|c|c|c|c|c|c|c|c|c|}
\hline & \multirow{3}{*}{$\begin{array}{r}2007 \\
\text { Dec. } \\
\text { Act. }\end{array}$} & \multicolumn{9}{|c|}{2008} \\
\hline & & \multirow{2}{*}{$\frac{\text { Mar. }}{\text { Act. }}$} & \multicolumn{3}{|c|}{ Jun. $^{1}$} & \multicolumn{3}{|c|}{ Sep. } & \multicolumn{2}{|c|}{ Dec. $^{1}$} \\
\hline & & & $\overline{\text { Prog. }}$ & $\begin{aligned} \text { Prog. } \\
\text { Adj. }\end{aligned}$ & $\overline{\text { Act. }}$ & Prog. & $\begin{array}{r}\text { Prog. } \\
\text { Adj. }\end{array}$ & $\overline{\text { Act. }}$ & Prog. & Proj. \\
\hline \multicolumn{11}{|l|}{ Performance Criteria } \\
\hline Net foreign assets of the BRB (floor; US\$ millions) ${ }^{2}$ & 67.5 & 59.3 & 67.4 & 55.7 & 53.1 & 15.9 & -3.4 & 63.3 & 16.9 & 33.3 \\
\hline Net domestic assets of the BRB (ceiling) ${ }^{2}$ & 49.4 & 48.4 & 51.6 & 65.2 & 71.6 & 124.9 & 146.9 & 71.3 & 117.1 & 113.8 \\
\hline Net domestic financing of the government (ceiling) ${ }^{2}$ & 8.5 & 19.1 & 37.3 & 50.9 & 37.7 & 21.6 & 43.6 & 26.0 & 13.2 & 13.2 \\
\hline External payments arrears of the government (ceiling; US $\$$ millions) ${ }^{3}$ & 0.0 & 0.0 & 0.0 & & 0.0 & 0.0 & & 0.0 & 0.0 & 0.0 \\
\hline Short-term external debt of the government (ceiling; US $\$$ millions) ${ }^{3}$ & 0.0 & 0.0 & 0.0 & & 0.0 & 0.0 & & 0.0 & 0.0 & 0.0 \\
\hline \multicolumn{11}{|l|}{$\begin{array}{l}\text { Nonconcessional external debt contracted or guaranteed by the } \\
\text { government or the BRB (ceiling; cumulative }\end{array}$} \\
\hline from the beginning of the calendar year; US $\$$ millions) ${ }^{3}$ & 0.0 & 0.0 & 0.0 & & 0.0 & 0.0 & & 0.0 & 0.0 & 0.0 \\
\hline \multicolumn{11}{|l|}{ Indicative targets } \\
\hline Government's wage bill (ceiling; cumulative from beginning of calendar year) & 114.0 & 34.2 & 70.3 & & 70.8 & 106.3 & & 108.7 & 141.2 & 151.7 \\
\hline Accumulation of domestic arrears (ceiling; cumulative from beginning of calendar year) & 0.0 & 0.5 & 0.0 & & 2.8 & 0.0 & & 3.3 & 0.0 & 3.3 \\
\hline
\end{tabular}

Indicative targets.

${ }^{2}$ The ceiling or the floor will be adjusted as indicated in the TMU.

${ }^{3}$ Continuous performance criterion. 
Table 4: Burundi: Performance Criteria and Indicative Targets for 2009

(Fbu billions, unless otherwise indicated)

\begin{tabular}{|c|c|c|c|c|}
\hline & \multicolumn{4}{|c|}{2009} \\
\hline & $\frac{\text { Mar. }}{\text { Prog. }}$ & $\frac{\text { Jun. }^{1}}{\text { Prog. }}$ & $\begin{aligned} \text { Sep. } \\
\text { Prog. }\end{aligned}$ & $\begin{array}{l}\text { Dec. }^{1} \\
\text { Prog. }\end{array}$ \\
\hline \multicolumn{5}{|l|}{ Performance Criterion } \\
\hline Net foreign assets of the BRB (floor; US\$ millions) ${ }^{2}$ & 15.4 & 10.4 & 11.0 & 21.6 \\
\hline Net domestic assets of the BRB (ceiling) ${ }^{2}$ & 126.7 & 146.8 & 155.4 & 147.2 \\
\hline Net domestic financing of the government (ceiling) ${ }^{2}$ & 36.5 & 46.9 & 61.2 & 0.0 \\
\hline External payments arrears of the government (ceiling; US $\$$ millions) ${ }^{3}$ & 0.0 & 0.0 & 0.0 & 0.0 \\
\hline Short-term external debt of the government (ceiling; US\$ millions) ${ }^{3}$ & 0.0 & 0.0 & 0.0 & 0.0 \\
\hline \multicolumn{5}{|l|}{$\begin{array}{l}\text { Nonconcessional external debt contracted or guaranteed by the } \\
\text { government or the BRB (ceiling; cumulative }\end{array}$} \\
\hline from the beginning of the calendar year; US\$ millions) ${ }^{3}$ & 0.0 & 0.0 & 0.0 & 0.0 \\
\hline \multicolumn{5}{|l|}{ Indicative targets } \\
\hline Government's wage bill (ceiling; cumulative from beginning of calendar year) & 38.9 & 86.7 & 141.7 & 180.4 \\
\hline Accumulation of domestic arrears (ceiling; cumulative from beginning of calendar year) & 0.0 & 0.0 & 0.0 & 0.0 \\
\hline Reserve money (ceiling) & 145.0 & 159.2 & 168.4 & 172.3 \\
\hline
\end{tabular}

\footnotetext{
1 Indicative targets.

${ }^{2}$ The ceiling or the floor will be adjusted as indicated in the TMU.

${ }^{3}$ Continuous performance criterion.
} 


\section{Table 5. Republic of Burundi: Performance Criteria and Structural Benchmarks for 2009}

\begin{tabular}{|c|c|c|}
\hline Measures & $\begin{array}{l}\text { Condition type } \\
\text { and date }\end{array}$ & Macroeconomic Rationale \\
\hline \multicolumn{3}{|l|}{ Fiscal management } \\
\hline $\begin{array}{l}\text { Resumption of payroll management by the } \\
\text { Ministry of Finance by taking charge of the } \\
\text { payroll database. }\end{array}$ & $\begin{array}{l}\text { Performance criterion } \\
\text { (March } 31,2009 \text { ) }\end{array}$ & $\begin{array}{l}\text { To reinforce wage bill management } \\
\text { through the creation of a single wage } \\
\text { data management and elimination of } \\
\text { ghost employees. }\end{array}$ \\
\hline $\begin{array}{l}\text { Close and transform into subaccounts for } \\
\text { special allocation from the general treasury } \\
\text { account the off-budget accounts mentioned } \\
\text { in the finance minister's letter No. } \\
540 / 4904 / 2008 \text { of November } 12,2008 \text {. }\end{array}$ & $\begin{array}{l}\text { Performance criterion } \\
\text { (September } 30,2009 \text { ) }\end{array}$ & $\begin{array}{l}\text { Continue implementation of single } \\
\text { Treasury account. }\end{array}$ \\
\hline $\begin{array}{l}\text { Close the accounts mentioned in the } \\
\text { finance minister's letter No. 540/4768/2008 } \\
\text { of October } 31,2008 \text {. }\end{array}$ & $\begin{array}{l}\text { Performance criterion } \\
\text { (September } 30,2009 \text { ) }\end{array}$ & $\begin{array}{l}\text { Continue implementation of single } \\
\text { Treasury account. }\end{array}$ \\
\hline $\begin{array}{l}\text { Prepare and implement a sliding quarterly } \\
\text { cash-flow plan. }\end{array}$ & $\begin{array}{l}\text { Structural benchmark } \\
\text { (June } 30,2009 \text { ) }\end{array}$ & $\begin{array}{l}\text { Enhance budget execution and ensure } \\
\text { coordination of monetary and budget } \\
\text { policies. }\end{array}$ \\
\hline \multicolumn{3}{|l|}{$\begin{array}{l}\text { Revenue administration and tax } \\
\text { policy }\end{array}$} \\
\hline $\begin{array}{l}\text { Introduce VAT and the common external } \\
\text { tariff. }\end{array}$ & $\begin{array}{l}\text { Structural benchmark } \\
\text { (July } 31,2009 \text { ) }\end{array}$ & $\begin{array}{l}\text { To raise efficiency of tax collection, and } \\
\text { offset potential losses on customs } \\
\text { revenue due to the accession to EAC. }\end{array}$ \\
\hline \multicolumn{3}{|l|}{ Fiscal governance } \\
\hline $\begin{array}{l}\text { In accordance with the laws of Burundi, the } \\
\text { Fbu } 6 \text { billion and the deeds for } \\
25 \text { properties belonging to INTERPETROL } \\
\text { that have been placed under seal will } \\
\text { remain in place until a court decision has } \\
\text { been reached on the INTERPETROL case. }\end{array}$ & $\begin{array}{l}\text { Performance criterion } \\
\text { (continuous) }\end{array}$ & $\begin{array}{l}\text { Enhance fiscal governance to ensure the } \\
\text { continuation of budget support. }\end{array}$ \\
\hline
\end{tabular}




\section{Attachment II. Burundi: Technical Memorandum of Understanding}

1. This technical memorandum of understanding covers the agreements on monitoring implementation of the program supported by the Poverty Reduction and Growth Facility (PRGF) arrangement. It sets out the definitions of program variables to monitor implementation of the program and the reporting requirements for the government of Burundi and the Bank of the Republic of Burundi (BRB). It defines quantitative performance criteria, indicative targets, and applicable adjusters.

\section{A. Quantitative Program Targets}

\section{Quantitative performance criteria and indicative targets}

2. The quantitative performance criteria under the program as shown in Table 4 of the MEFP are as follows:

- $\quad$ net foreign assets of the BRB (floor);

- $\quad$ net domestic assets of the BRB (ceiling);

- $\quad$ net domestic financing of the government (ceiling);

- $\quad$ external payments arrears of the government (ceiling; continuous);

- $\quad$ stock of short-term external debt (maturity of less than one year) of the government and the BRB (ceiling; continuous); and

- new nonconcessional medium- and long-term external debt contracted or guaranteed by the government or the BRB (ceiling; continuous).

3. The quantitative indicative targets under the program, shown in Tables 4 of the MEFP, are as follows:

- the government's wage bill (ceiling).

- $\quad$ accumulation of domestic arrears (ceiling).

- $\quad$ reserve money (ceiling). 


\section{Definitions and measurement}

4. The net foreign assets of the BRB are defined as the difference between (i) gross official reserves (valued at market prices) and other claims; and (ii) foreign exchange liabilities to nonresident entities (including the use of Fund resources, but excluding the counterpart of SDR allocations). The gross official reserves of the BRB are defined as those foreign assets that are liquid and freely available to the central bank.

5. The net domestic assets of the BRB are defined as the difference between (i) reserve money, comprising currency in circulation, reserves of commercial banks, and other deposits held at the BRB; and (ii) net foreign assets of the BRB.

\section{Adjuster for changes in the compulsory reserves coefficients}

6. The ceiling on net domestic assets of the BRB will be adjusted symmetrically for any change in the compulsory reserves coefficient applied to deposits in the commercial banks, by the amount of the new coefficient minus that stipulated in the program, multiplied by bank deposits subject to compulsory reserves. The rate stipulated in the program is currently 3 percent.

7. Net domestic financing of the government is defined as the change in (i) outstanding loans, advances, and other credit to the government from the BRB and all of Burundi's commercial banks; (ii) the stock of all government securities held by the non-bank public denominated in Burundi francs, including that held by nonresidents; (iii) less government deposits held in the BRB or in Burundi's commercial banks. The coverage of government is defined as central government and any other special funds or operations that are part of the budgetary process or have a direct impact on the government's financial position.

8. The stock of external payments arrears for program monitoring purposes is defined as the end-of-period amount of external debt service due and not paid, including contractual and late interest, for which a clearance agreement is not in place or for which arrears are not reschedulable. Arrears for which a clearance framework has been agreed with the creditor or which are subject to rescheduling or restructuring are not considered arrears for program monitoring purposes. Program arrears would include any debt service due under such agreements that have not been paid.

9. The program includes a ceiling on new nonconcessional external debts contracted or guaranteed by the government and the BRB. This performance criterion applies to the contracting or guaranteeing by the central government, local governments, or the BRB of new nonconcessional external debt (as specified below) with an original maturity of one year or more, including commitments contracted or guaranteed for which value has not been received. The term "debt" shall be understood as defined in the Executive Board Decision 
No. 12274-(00/85) adopted August 24, 2000. Debt rescheduling and restructuring are excluded from the criterion. Included are financial leases and other instruments giving rise to external liabilities, contingent or otherwise, on nonconcessional terms. In determining the level of concessionality of these obligations, the definition of concessional borrowing shall apply. Concessional debt is defined as having a grant element of 50 percent or more. Management fees would also be taken into account when determining a loan's grant element. For loans with a maturity of at least 15 years, the 10-year average commercial interest reference rates (CIRRs) published by the OECD should be used as the discount rate for assessing the level of concessionality, while the 6-month average CIRRs should be used for loans with shorter maturities. To both the 10-year and the 6-month average CIRRs, the following margins should be added: 0.75 percent for repayment periods of less than 15 years; 1 percent for 15-19 years; 1.15 percent for 20-29 years; and 1.25 percent for 30 years or more. The performance criterion is defined to exclude the use of Fund resources and any Burundi franc-denominated treasury securities held by nonresidents.

10. The stock of short-term external debt with a maturity of less than one year, owed by the central government is to remain at zero under the program. Normal import credits are excluded from this ceiling. Loans with an initial maturity, as recorded in the original loan agreement, of one year or more are considered medium-term or long-term loans. This performance criterion applies not only to debt, as defined in point No. 9 of the Guidelines on Performance Criteria with Respect to Foreign Debt, adopted August 24, 2000, but also to commitments contracted or guaranteed for which value has not been received (including leasing). Excluded from this performance criterion are rescheduling arrangements, borrowing from the Fund, and any Burundi franc-denominated treasury securities held by nonresidents. As of end-September 2007, the stock of short-term debt outstanding was nil.

11. The government's wage bill is defined as total labor remunerations on a commitments basis for civil servants, contractual employees, police, and military personnel of the government, including all allowances and bonuses.

12. The accumulation of domestic arrears is measured by the accumulation of nonexecuted payment orders older than 60 days.

\section{External financial assistance adjustor}

13. The program provides for adjusters to allow higher than expected external assistance to be spent (with a cap) and shortfall of external assistance to be financed domestically (with a cap).

14. Any financing excess up to US\$60 million will be spent on expenditure priorities defined in the PRSP. The floor on the stock of net foreign assets of the central bank will be adjusted upward, and the ceilings on the net domestic assets of the central bank and on the 
net domestic financing to the government will be adjusted downward to accommodate 100 percent of any financing excess above US\$60 million.

15. The floor on the stock of net foreign assets of the central bank will be adjusted downward, and the ceilings on the net domestic assets of the central bank and on the net domestic financing to the government will be adjusted upward to accommodate a financing shortfall up a maximum of US\$60 million. External financial assistance will be converted to Burundi francs using the program-specified $\mathrm{FBu} / \mathrm{US} \$$ exchange rate.

16. External financial assistance (measured in US\$) is defined to include the following: (i) nonproject loans and grants to the budget (including payments made through the multidonor trust fund managed by the World Bank for current debt service to multilaterals); (ii) debt relief on current maturities; minus (iii) any cash payments for external arrears clearance operations. Donor disbursements into blocked accounts for the purpose of clearing arrears will not be included as foreign assistance for program monitoring purposes.

\section{B. Provision of Information to IMF Staff}

17. To facilitate the monitoring of program implementation, the authorities will prepare and forward to the IMF African Department a monthly progress report on the program, within six weeks of the end of each month, containing:

18. The following weekly data:

- $\quad$ foreign exchange auction market (MED) transactions;

- $\quad$ the balance sheet of the BRB (weekly statement) (BRB Research Department).

19. The following monthly data, with a maximum lag of six weeks:

- $\quad$ a monitoring table (tableau de bord) containing the most recent weekly and monthly data on the main financial indicators (REFES);

- $\quad$ a table on the foreign exchange cash-flow (BRB Foreign Banking Operations Department);

- $\quad$ the monetary survey, including the breakdown of the central bank and of commercial banks (BRB Research Department);

- $\quad$ monthly exchange-rate data (official and parallel markets, end-of-month and monthly average) (BRB Research Department);

- $\quad$ a detailed breakdown of government revenue (Ministry of Finance);

- $\quad$ a detailed breakdown of government expenditure on a commitment basis, including pro-poor spending (Ministry of Finance); 
- a detailed breakdown of the servicing of domestic and external public debt, including amounts due and paid, in interest and principal, as well as the breakdown by creditor and any accumulation of arrears on domestic or external debt (Ministry of Finance);

- $\quad$ a detailed breakdown of the stock of domestic payments arrears for the current fiscal year (Ministry of Finance);

- $\quad$ the amount of new debts contracted or guaranteed by the government, including detailed information on the terms (such as currency denomination, interest rate, grace period, maturity) (Ministry of Finance);

- $\quad$ actual disbursements of nonproject financial assistance, including new loans and debt relief granted by Burundi's external creditors (Ministry of Finance); and

- $\quad$ an update on the implementation of structural measures planned under the program (REFES).

20. The following quarterly data, with a maximum lag of six weeks:

- $\quad$ Progress reports on the BRB's internal reforms, including each unit's action plans for the coming month (Reform Monitoring Committee, BRB).

21. SP/REFES/Ministry of Finance and BRB will also provide the African Department of the IMF with any information that is deemed necessary to ensure effective monitoring of the program. 
INTERNATIONAL MONETARY FUND

BURUNDI

First Review Under the Three-Year Arrangement Under the Poverty Reduction and Growth Facility

\section{Informational Annex}

Prepared by the African Department

(In consultation with other departments)

January 8, 2009

Contents

Page

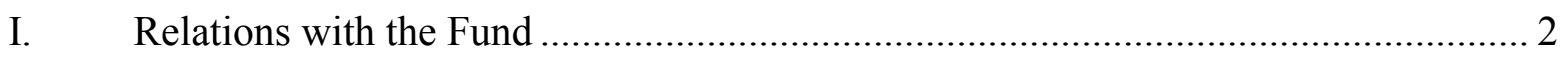

II. Joint World Bank-IMF Work Program, 2008-09 ………........................................ 7

III. Relations with the African Development Bank Group .............................................. 8

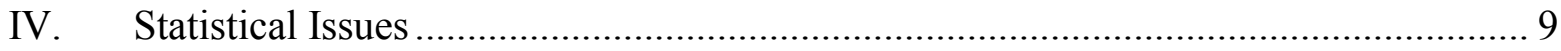




\section{ANNEX I. BURUNDI: RELATIONS WITH THE FUND}

(As of November 30, 2008)

I. Membership Status: Joined: September 28, 1963; Article XIV

II. General Resources Account:

Quota

Fund holdings of currency

Reserve position

Holdings exchange rate

\section{SDR Department:}

Net cumulative allocation

Holdings

IV. Outstanding Purchases and Loans:

PRGF arrangements

$$
\begin{array}{rr}
\text { SDR Million } & \text { \%Quota } \\
77.00 & 100.00 \\
76.64 & 99.53 \\
0.36 & 0.47
\end{array}
$$

$\begin{array}{rr}\text { SDR Million } & \text { \%Allocation } \\ 13.70 & 100.00 \\ 0.08 & 0.62\end{array}$

SDR Million

$\%$ Quota

75.90

98.57

\section{Latest Financial Arrangements:}

$\begin{array}{rllrr}\text { Type } & \begin{array}{c}\text { Date of } \\ \text { Arrangement }\end{array} & \begin{array}{c}\text { Expiration } \\ \text { Date }\end{array} & \begin{array}{c}\text { Amount Approved } \\ \text { (SDR Million) }\end{array} & \begin{array}{c}\text { Amount Drawn } \\ \text { (SDR Million) }\end{array} \\ \text { PRGF } & \begin{array}{l}\text { Jul 07, 2008 } \\ \text { Jul 06, 2011 }\end{array} & 46.20 & 6.60 \\ \text { PRGF } & \text { Jan 23, 2004 } & \text { Jan 22, 2008 } & 69.30 & 69.30 \\ \text { PRGF } & \text { Nov 13, 1991 } & \text { Nov 12, 1994 } & 42.70 & 17.21\end{array}$

\section{Projected Payments to Fund ${ }^{1}$}

(SDR Million; based on existing use of resources and present holdings of SDRs):

Principal

\begin{tabular}{|c|c|c|c|c|}
\hline 2008 & 2009 & 2010 & 2011 & 2012 \\
\hline & 2.64 & 6.00 & 8.14 & 11.72 \\
\hline$\underline{0.19}$ & $\underline{0.52}$ & $\underline{0.49}$ & $\underline{0.45}$ & $\underline{0.40}$ \\
\hline 0.19 & 3.16 & 6.49 & $\overline{8.59}$ & $1 \overline{2.12}$ \\
\hline
\end{tabular}

Charges/Interest

Total
Forthcoming

\footnotetext{
${ }^{1}$ When a member has financial obligations overdue for more than three months, the amount of such arrears will be shown in this section.
} 


\section{Safeguards Assessments}

An update assessment of the Banque de la République du Burundi (BRB) was completed in June 2008 and found that since the previous assessment, certain safeguards had been strengthened (e.g., external audits have been completed on a timelier basis and audited financial statements comply with IFRS and are published). However, the 2008 assessment also identified significant control weaknesses and recommended more robust controls over domestic disbursements to the government and its creditors, including contracting an external auditor to review such controls (Prior Actions for the approval of the arrangement). Other key safeguards recommendations include a system to monitor the status of audit and safeguards recommendations, continuation of semi-annual audits of disbursements to the government, and establishing guidelines for investment operations.

\section{Exchange Arrangements}

Burundi maintains a managed float exchange regime. The U.S. dollar is the intervention currency. On December 31, 2008, the exchange rate was Fbu 1,234.98 to the US dollar. In 2003, the central bank eliminated most remaining exchange restrictions on current international transactions and delegated authority to commercial banks to approve standard transactions. In early 2004, the surrender requirement was lowered to 50 percent and in early 2005 it was eliminated. The central bank admitted foreign exchange bureaus to the weekly auctions. Most external payments arrears to bilateral and multilateral creditors were cleared by the end of 2005. In December 2006, the government published a new foreign exchange regulation, which liberalized foreign exchange for current transactions and removed one multiple currency practice.

Burundi availed itself of the transitional arrangements of Article XIV when it joined the Fund in 1963 but no longer maintains any exchange restrictions or multiple currency practices that relate to Article XIV. It does have one multiple currency practice that is inconsistent with Article VIII, Section 2(a): the exchange rate used for government transactions may differ by more than 2 percent from market exchange rates. Burundi maintains certain foreign exchange restrictions for security reasons and has notified the Fund of those restrictions pursuant to Decision 144-(52/51). The authorities have not requested, and staff does not propose, approval of the multiple currency practice.

\section{Article IV Consultation}

In accordance with Decision 12794-(02/76), as amended by Decision 12854-(02/96), Burundi is on the 24-month Article IV cycle. The 2008 Article IV consultation was completed by the Executive Board on July 7, 2008 (Country Report 08/77), along with the request for a new arrangement under the PRGF. 
In concluding the 2008 consultation, Executive Directors acknowledged the commendable progress that Burundi made in implementing its PRGF-supported program in a difficult postconflict environment. They agreed that fiscal sustainability in the face of a heavy debt burden will depend on broadening the revenue base and improving the composition of spending while financing the budget through grants and highly concessional external resources. Against the background of the recent acceleration of inflation deriving from rising international food and oil prices, Directors encouraged the monetary authorities to act to anchor inflation expectations and contain second-round effects of food and oil price shocks. Directors saw the need to accelerate structural reforms, especially in the coffee sector, and welcomed Burundi's membership in the East African Community. 


\title{
X. Technical Assistance
}

\author{
2008 (May) FAD mission for installation of a PFM resident advisor \\ 2008 (Jan.) $\quad$ FIN safeguards assessment mission \\ 2007 (Dec.) $\quad$ AFRITAC statistics mission on national accounts and consumer price index \\ 2007 (Nov./Dec.) STA monetary and financial statistics mission \\ 2007 (Nov.) AFRITAC capacity building in banking supervision mission \\ 2007 (Nov.) FAD tax policy mission \\ 2007 (Nov.) STA monetary statistics mission \\ 2007 (Sep.) MCM multi-topic mission \\ 2007 (Sep.) AFRITAC tax revenue administration \\ 2007 (Sep.) AFRITAC capacity building of central bank mission \\ 2007 (Sep.) $\quad$ FAD public financial management mission \\ 2007 (Jul.) $\quad$ AFRITAC PFM on payroll control \\ 2007 (Jun.) AFRITAC PFM mission on treasury operation and control \\ 2007 (Jun.) MCM technical assistance mission \\ 2007 (Jun.) AFRITAC capacity building on debt management mission \\ 2007 (Mar.) $\quad$ FAD resident expert on public accounting \\ 2006 (Dec.) FAD public expenditure management mission \\ 2006 (Nov.) MCM banking supervision mission \\ 2006 (Sep.) $\quad$ FAD customs and tax administration mission \\ 2006 (Apr.) MCM foreign exchange reserve management mission \\ 2006 (Mar.) STA mission to prepare the metadata and medium-term action plan \\ 2006 (Mar.) MFD/LEG joint Article VIII mission \\ 2006 (Jan.) LEG AML/CFT legislative drafting mission \\ 2006 (Jan.) Monetary operations/FOREX/banking supervision mission
}




\section{Implementation of HIPC Initiative:}

Enhanced

I. Commitment of HIPC assistance

Framework

Decision point date

Aug 2005

Assistance committed

by all creditors (US\$ million) ${ }^{1}$

826.00

Of which: IMF assistance (US\$ million)

(SDR equivalent in

millions)

Completion point date

19.26

Floating

II. Disbursement of IMF assistance (SDR Million)

Assistance disbursed to the member

0.26

Interim assistance

0.26

Completion point balance

Additional disbursement of interest income ${ }^{2}$

Total disbursements

\footnotetext{
${ }^{1}$ Assistance committed under the original framework is expressed in net present value (NPV) terms at the completion point, and assistance committed under the enhanced framework is expressed in NPV terms at the decision point. Hence these two amounts cannot be added.

${ }^{2}$ Under the enhanced framework, an additional disbursement is made at the completion point corresponding to interest income earned on the amount committed at the decision point but not disbursed during the interim period.
}

\section{Resident Representative:}

A part-time Resident Representative took up the post in May 2005 and an office with an administrative assistant opened in January 2006 in Bujumbura. Mr. Israel de la Piedra has been the IMF's Resident Representative to Burundi since May 2007. 
ANNEX II. Burundi: Joint World BANK-IMF Work Program, 2008-09

\begin{tabular}{|c|c|c|c|}
\hline Title & Products & $\begin{array}{c}\text { Provisional timing of } \\
\text { Mission }\end{array}$ & $\begin{array}{c}\text { Expected Delivery } \\
\text { Date }\end{array}$ \\
\hline \multicolumn{4}{|c|}{ A. Mutual Information on Relevant Work Programs } \\
\hline \multirow[t]{5}{*}{$\begin{array}{l}\text { Bank work program in } \\
\text { next } 12 \text { months }\end{array}$} & $\begin{array}{l}\text { 1. Public Expenditure } \\
\text { Management and } \\
\text { Financial Accountability } \\
\text { Review (PEMFAR) } \\
\text { 2. ERSG2 (Budget }\end{array}$ & July 2008 & August 2008 \\
\hline & $\begin{array}{l}\text { support) } \\
\text { 3.ERSG3 (Budget }\end{array}$ & $\begin{array}{l}\text { March 17-28 } \\
\text { (appraisal) }\end{array}$ & July 2008 \\
\hline & support) & $\begin{array}{l}\text { Sept 08. (identification) } \\
\text { Nov.. 08. (pre- } \\
\text { appraisal) } \\
\text { March } 09 \text { (appraisal) }\end{array}$ & July 2009 \\
\hline & 4. Country Economic & Sept.-Nov. 08 & \\
\hline & Memorandum (CEM) & $\begin{array}{l}\text { August } 09 \text { (main } \\
\text { mission) }\end{array}$ & March-May 2010 \\
\hline \multirow{4}{*}{$\begin{array}{l}\text { IMF work program in } \\
\text { next } 12 \text { months }\end{array}$} & 1. Article IV & April 30-May 14 and & July 2008 \\
\hline & $\begin{array}{l}\text { consultation, } \\
\text { negotiations for new } \\
\text { PRGF arrangement }\end{array}$ & 008 & \\
\hline & 2. First PRGF review & October 2008 & $\begin{array}{l}\text { December 2008/ } \\
\text { January } 2009\end{array}$ \\
\hline & $\begin{array}{l}\text { 3. Second PRGF } \\
\text { review }\end{array}$ & April 2009 & July 2009 \\
\hline \multicolumn{4}{|c|}{ B. Requests for Work Program Inputs } \\
\hline Fund request to Bank & $\begin{array}{l}\text { 1. Policy note on } \\
\text { domestic petroleum } \\
\text { sector }\end{array}$ & & $\begin{array}{l}\text { September/October } \\
2008\end{array}$ \\
\hline \multirow[t]{2}{*}{ Bank request to Fund } & $\begin{array}{l}\text { 1. Study of exchange } \\
\text { rate misalignment and } \\
\text { competitiveness }\end{array}$ & & July 2008 \\
\hline & $\begin{array}{l}\text { 2. Study on the sources } \\
\text { of inflation in Burundi }\end{array}$ & & December 2009 \\
\hline & C. Agreement on Joint & Products and Missions & \\
\hline \multirow{3}{*}{$\begin{array}{l}\text { Joint products in next } \\
12 \text { months }\end{array}$} & FSAP & & December 2008 \\
\hline & DSA & & December 2008 \\
\hline & HIPC CP Documents & & \\
\hline
\end{tabular}




\section{AnNeX III. Burundi: Relations With the AFriCAn DEVElopMent BanK Group}

(As of January 31, 2008)

Burundi has been a member of the African Development Bank (AfDB) Group since the group's foundation in 1964. AfDB grant and loan operations with the country were interrupted by the outbreak of civil strife in 1993. On July 19, 2004, the AfDB Boards approved general policy guidelines to help postconflict countries to clear their arrears and created a facility, the PCCF, initially funded with about SDR 100 million in AfDB funds, to provide financial assistance to qualifying countries. The policy guidelines call for a three-way burden-sharing formula among the country, donors, and the PCCF. On October 27, 2004, the AfDB Boards endorsed an arrears clearance proposal for Burundi whereby the balance of arrears was settled with the help of donors and the PCCF before the decision point for the enhanced HIPC Initiative.

On November 24, 2005, the Boards of Directors of the AfDB and the African Development Fund (ADF) agreed that Burundi had effectively met the conditions and reached the decision point for the enhanced framework of the Heavily Indebted Poor Countries (HIPC) Initiative. The AfDB Group's share of debt relief will amount to US\$149.35 million in present value terms (US\$226.01 million in nominal terms), which is equivalent to about 21 percent of multilateral creditors' assistance and about 18 percent of assistance from all creditors. This amount will save up to 90 percent of Burundi's debt-service obligations annually until February 2043.

Under its FAD 9 allocation, following the lifting of sanctions in October 2004, on July 7, 2004, the AfDB approved a grant of SDR 2.13 million to finance training of civil servants and procurement of equipment for institutions in charge of economic management and civil society. A structural adjustment credit of SDR 6.72 million, in one tranche, accompanied by a further grant of SDR 1.5 million for institutional support, was approved by the Board on December 2004. A multisector project totaling SDR 9.8 million was also approved in December 2004. Under its FAD 10 allocation, the AfDB approved in December 2005 a grant of SDR 12 million to finance rural water infrastructure rehabilitation and in March 2006 a grant of SDR 9 million to finance the watershed management project. In November 2006, the AfDB approved one more grant, SDR 7.3 million in one tranche, to finance economic reforms and governance support.

\begin{tabular}{|lcc|}
\hline \multicolumn{3}{|c|}{ African Development Bank Operations in Burundi } \\
\hline & $\begin{array}{c}\text { Outstanding } \\
\text { loans } \\
\text { (In millions of SDRs) }\end{array}$ & $\begin{array}{c}\text { Past-due } \\
\text { obligations }\end{array}$ \\
\hline African Development Fund & 138.7 & 0 \\
Nigerian Trust Fund & 1.4 & 0 \\
Total & $\mathbf{1 4 0 . 1}$ & $\mathbf{0}$ \\
\hline
\end{tabular}




\section{ANNEX IV. BuRUndi: STATISTICAL ISSUES}

Burundi's data have serious shortcomings that significantly hamper surveillance. The most acute shortcomings affect national accounts, government finance, and balance of payments statistics. STA missions have found that staffing shortages, insufficient funding, and lack of equipment impede production and dissemination of macroeconomic statistics. Coordination among institutions responsible for compiling statistics has been poor.

After the authorities expressed interest in participating in the General Data Dissemination System (GDDS), in March 2006 a mission helped them to prepare metadata and, in collaboration with the World Bank and donors, draft a remedial plan. The authorities referred to this action plan in the Poverty Reduction Strategy Paper that was approved in September 2007 and a national statistical development strategy is being prepared with donor assistance. On September 25, 2007, the government promulgated a new statistics law, and in December 2007 the accompanying regulatory texts were approved. Burundi is expected to become a GDDS participant, once the authorities complete reviewing the metadata.

\section{Outstanding statistical issues}

\section{Real sector}

Serious deficiencies in real sector data handicap analysis and economic management. National accounts are compiled infrequently. Source data on agriculture, the most important activity, is weak. Since 1998 Burundi has reported annual national accounts estimates to the Fund with about a three-month lag, but these are derived from a macroeconomic projection model maintained by the Ministry of Economy, Finance, and Development Cooperation (MEFD). Recently, the Statistical Office is in the process of developing, with AFRISTAT's help, a set of provisional national accounts for 2005, the new base year. This is a major effort because the last national accounts data were from 1998.

The CPI is compiled monthly. Its coverage has been extended to include provinces as well as the capital, Bujumbura. Weights, which are based on a 1991 household expenditure survey, are in the process of being revised. There are no producer price indices, and the data on employment are out of date.

\section{Government finance}

The central bank compiles government finance statistics using source data from the MEFD. Until recently, ministries seldom maintained computerized ledgers, making it impossible to establish balances and other accounting controls. Little accounting information was available on extrabudgetary units. There were also problems in recording arrears on external debt and current expenditure financed by foreign grants, which led to significant discrepancies between the balance of revenue and expenditure and financing estimates. With World Bank 
and FAD assistance, improved public financial management information systems that generate, among other things, standard quarterly budget execution reports implemented in 2005 are now largely operational. These improvements have brought better and faster compilation of government finance statistics. STA has provided training in government finance statistics to compilers both at the Joint Africa Institute and INS. However, the coverage and quality need to be improved. Summary government finance statistics transactions data through July 2007 have been reported in International Finance Statistics. No annual GFS data have been reported to STA for dissemination since 1999.

\section{Monetary statistics}

An STA technical assistance mission from November 22-December 4, 2007 helped the BRB improve its monetary and financial statistics. As a result, the monetary statistics it compiles largely follow the Monetary and Financial Statistics Manual methodology, which should make it easier to harmonize Burundi's monetary statistics to those of other members of the East African Community. The BRB has completed migration to the Standardized Report Forms for the submission of its monetary statistics to the Fund, and they were published in the June 2008 issue of the IFS Monetary and Financial Statistics Supplement. With the support of the 2007 mission, the BRB compiled an enlarged broad money aggregate (M3) that is planned to replace M2, which does not include deposits in foreign currencies.

\section{Balance of payments}

Annual balance of payments and international investment position statistics are compiled according to the fifth edition of the Balance of Payments Manual (BPM5). Merchandise trade statistics are derived from customs data, but no adjustments are made for unrecorded international trade flows, such as gifts in kind that do not go through the banking system. Data for services are collected mostly from monthly bank settlement reports. Income estimates are almost exclusively derived from those reports. For both services and income, the accuracy of the source data is not routinely assessed against other data sources. Data on current and capital transfers, as well as on financial accounts, are incomplete; further BRB action is needed to improve their quality and reliability. Balance of payments and international investment position data are published in International Financial Statistics and in the Balance of Payments Yearbook through 2006. 
Burundi: Table of Common Indicators Required for Surveillance

(As of November 30, 2008)

\begin{tabular}{|c|c|c|c|c|c|}
\hline & $\begin{array}{l}\text { Date of } \\
\text { Latest } \\
\text { Observation }\end{array}$ & $\begin{array}{l}\text { Date } \\
\text { Received }\end{array}$ & $\begin{array}{l}\text { Frequency } \\
\text { of Data }^{7}\end{array}$ & $\begin{array}{l}\text { Frequency of } \\
\text { Reporting }\end{array}$ & $\begin{array}{l}\text { Frequency } \\
\text { of } \\
\text { Publication }^{7}\end{array}$ \\
\hline Exchange Rates & Current & Current & $\mathrm{D}$ & M & M \\
\hline $\begin{array}{l}\text { International Reserve Assets and } \\
\text { Reserve Liabilities of the Monetary } \\
\text { Authorities }^{1}\end{array}$ & Oct. 2008 & Nov. 2008 & M & $M$ & M \\
\hline Reserve/Base Money & Oct. 2008 & Nov. 2008 & M & M & M \\
\hline Broad Money & Oct. 2008 & Nov. 2008 & M & $M$ & M \\
\hline Central Bank Balance Sheet & Oct. 2008 & Nov. 2008 & M & M & M \\
\hline $\begin{array}{l}\text { Consolidated Balance Sheet of the } \\
\text { Banking System }\end{array}$ & Oct. 2008 & Nov. 2008 & M & $M$ & M \\
\hline Interest Rates $^{2}$ & Jun. 2008 & Nov. 2008 & $M$ & $M$ & $M$ \\
\hline Consumer Price Index & Oct. 2008 & Nov. 2008 & M & M & $M$ \\
\hline $\begin{array}{l}\text { Revenue, Expenditure, Balance } \\
\text { and Composition of Financing }{ }^{3}- \\
\text { General Government }^{4}\end{array}$ & NA & NA & NA & NA & NA \\
\hline $\begin{array}{l}\text { Revenue, Expenditure, Balance } \\
\text { and Composition of Financing }{ }^{3}- \\
\text { Central Government }\end{array}$ & Sep. 2008 & Nov. 2008 & $Q$ & $Q$ & $Q$ \\
\hline $\begin{array}{l}\text { Stocks of Central Government and } \\
\text { Central Government-Guaranteed } \\
\text { Debt }^{5}\end{array}$ & NA & NA & NA & NA & NA \\
\hline External Current Account Balance & Dec. 2007 & Nov. 2008 & A & $A$ & $A$ \\
\hline $\begin{array}{l}\text { Exports and Imports of Goods and } \\
\text { Services }\end{array}$ & Dec. 2007 & Nov. 2008 & M & M & M \\
\hline GDP/GNP & Dec. 2007 & Nov. 2008 & A & $A$ & A \\
\hline Gross External Debt & Dec. 2007 & Nov. 2008 & M & M & $A$ \\
\hline International Investment Position ${ }^{6}$ & Dec. 2007 & Oct. 2008 & A & A & A \\
\hline \multicolumn{6}{|c|}{$\begin{array}{l}{ }^{1} \text { Includes reserve assets pledged or otherwise encumbered, as well as net derivative positions. } \\
{ }^{2} \text { Both market-based and officially determined, including discount rates, money market rates, rates on treasury bills, notes and } \\
\text { bonds. } \\
33 \text { Foreign, domestic bank, and domestic nonbank financing. } \\
4 \text { The general government consists of the central government (budgetary funds, extra budgetary funds, and social security } \\
\text { funds), and state and local governments. } \\
5 \text { Including currency and maturity composition. } \\
6 \text { Includes external gross financial asset and liability positions vis a vis nonresidents. } \\
{ }^{7} \text { Daily (D), weekly (W), monthly (M), quarterly (Q), annually (A), irregular (I); and not available (NA). }\end{array}$} \\
\hline
\end{tabular}


Press Release No. 09/17

International Monetary Fund

FOR IMMEDIATE RELEASE

Washington, D.C. 20431 USA

January 26, 2009

\section{IMF Completes First Review under PRGF Arrangement with Burundi and Approves US\$9.9 Disbursement}

The Executive Board of the International Monetary Fund (IMF) today completed the first review of Burundi's economic performance under a program supported by a three-year Poverty Reduction and Growth Facility (PRGF) arrangement. The completion of the review enables the immediate disbursement of an amount equivalent to SDR 6.6 million (about US\$9.9 million), bringing total disbursements under the program to an amount equivalent to SDR 13.2 million (about US\$19.9 million).

The PRGF arrangement was approved on July 7, 2008 (see Press Release No 08/167) for an amount equivalent to SDR 46.2 million (about US\$69.6 million).

Following the Executive Board's discussion on Burundi, Mr. Murilo Portugal, Deputy Managing Director and Acting Chair, stated:

"The Burundian authorities are to be commended for their strong performance under the PRGF supported program in a difficult political and economic environment. Burundi has met the conditions for reaching the completion point under the Enhanced Heavily Indebted Poor Countries (HIPC) Initiative. Consequently, it qualifies for additional assistance under the Multilateral Debt Relief Initiative (MDRI).

“The program for 2009 should further consolidate macroeconomic stability and reduce poverty. Prudent monetary policy will help anchor inflation expectations while allowing sufficient scope for economic growth. Spending on MDG-related sectors will be boosted significantly, supported by HIPC Initiative and MDRI debt relief.

"The achievement of the country's medium-term objectives of sustained growth and poverty reduction will depend on maintaining prudent macroeconomic policies and accelerating structural reforms. The authorities should continue to rely mainly on grants and highly concessional loans to keep debt sustainable," Mr. Portugal said. 


\section{Statement by Samuel Itam, Executive Director for Burundi January 28, 2009}

1. My Burundian authorities are persevering with the consolidation of post-conflict reconstruction, macroeconomic stability, as well as public accountability and structural reforms. Building on the broad-based economic growth, they are determined to maintain the momentum in the near to medium term. The authorities appreciate the constructive engagement and support of the Fund, the World Bank and the donor community. In particular, they thank staff for their candid policy dialogue and advice, which has been invaluable in the effort to raise and sustain growth and to reduce poverty.

2. The implementation of the PRGF- supported program since its inception in July 2008 has been strong. All the quantitative and structural performance criteria for end-September 2008 were met. Progress in the implementation of the reform agenda has been impressive. Moreover, six of the nine triggers for reaching the enhanced HIPC completion point were implemented fully, and substantial progress made in implementing the remaining three demobilization, the coffee sector and the social sectors. By all measures, the later three were indeed very challenging triggers for the country.

- A ceasefire agreement was reached with the last remaining rebel group far later than had been envisaged, and the power-sharing understandings were signed only last month. Nevertheless, substantial progress was made towards the targets for demobilization, reinsertion and reintegration.

- Once the authorities started making plans to tender for sale the state holdings in a majority of coffee washing stations, they realized that the reforms required in the industry have to be more deep-seated if the benefits are to be maximized. Hence, Burundi decided on a more ambitious reform than was envisaged but with the confidence that the results would be more acceptable to all stakeholders and durable.

- The authorities are strongly committed to improvements in the social sectors particularly education and health. However, progress has been much slower than what they would have desired. Coming from a very difficult conflict period, the authorities may have underestimated the substantial effort required to restore even the basic building blocks for the system to start delivering acceptable results. Nonetheless, they are determined. While the goals for the social sectors may, in retrospect, have been somewhat ambitious, the authorities expect to attain them in the very near future. In this regard, they are appreciative of the assistance that has been provided by development partners.

3. In view of the good economic performance and the continued commitment to reforms under the program, the authorities request Directors' support for (i) the completion of the first review under the PRGF arrangement, (ii) the country to reach the completion point under the enhanced HIPC, and (iii) debt relief under the MDRI. 


\section{Recent economic developments and program performance}

4. Burundi's macroeconomic performance continued to be strong, with real GDP growth estimated to have averaged $4 \frac{1}{2}$ percent a year in 2006-07. Economic growth was led by good coffee harvest and increased donor-funded investment projects. However, due to high international prices for oil and food, inflation has surged to double digits and it is estimated to have reached 22 percent at end-December 2008. This contributed to the significant appreciation of the real exchange rate, although exports appear not to have been adversely affected during the year. Overall, fiscal performance continued to be in line with the program because higher-than-programmed expenditures were mostly financed by larger-thanprogrammed aid.

5. Medium-term macroeconomic prospects are generally positive. Growth is expected to be supported by increased investment expenditure, a rebound in food production, and the positive supply shock of falling oil prices. Trade liberalization under the auspices of the East African Community (EAC) is expected to assist in economic diversification and market expansion. Downside risks are expected to emanate from the global economic slowdown as well as the political and social uncertainty.

6. Considerable progress has been made in implementing structural reforms. Parliament has adopted a new organic law, which will facilitate the authorities' efforts to improve fiscal management and transparency. The action plan for phasing out the transaction tax and introducing value added tax (VAT) has also been approved by the council of ministers. With regard to the financial sector, parliament has adopted a new law enhancing central bank independence and governance, and the central bank has put in place measures to improve its risk management. New investment legislation, aimed at improving the investment climate, has also been promulgated.

\section{Policies for 2009 and the medium term}

7. The authorities remain steadfast to maintaining a stable macroeconomic environment, creating conditions for sustained broad-based economic growth and poverty reduction, and persevere with the structural reform agenda. Efforts to create employment opportunities through significant public investment in infrastructure and reforms to the business environment remain priorities. They are counting the HIPC and MDRI to contribute to substantial reduction of the country's heavy debt burden, but also to support their prudent fiscal and monetary policies. Notwithstanding the recorded strong macroeconomic performance, the authorities concur with staff assessment that the country faces a number of economic, social, security, and exogenous challenges going forward.

\section{Fiscal policy}

8. The authorities will continue to pursue prudent fiscal policies in the medium term, aimed at limiting debt-creating domestic financing while providing fiscal space for increased 
investments in agriculture and key MDG clusters. The main elements of the authorities' fiscal program include renewed efforts to enhance revenue collection, increasing public investment in infrastructure and improving productivity in agriculture, while continuing with efforts to streamline public expenditure and target zero net domestic financing.

9. The authorities are confident, and staff concur, that domestic revenue mobilization effort would improve if current efforts are sustained. This would largely entail broadening the tax base, strengthening fiscal controls, and reducing discretionary tax exemptions. The authorities will continue implementing the modernization program for the tax revenue authorities and prepare for the introduction of the value-added tax and the adoption of EAC common external tariff (CET) in the near term.

10. On the expenditure side, the authorities intend to consolidate current outlays as a percentage of GDP, while increasing spending on priority sectors in line with the country's poverty reduction strategy. Spending would target improving access to basic social services, particularly in education and health, as well as improving access to public facilities like water, electricity and roads in the rural areas.

11. To ensure credibility and make spending more effective, the authorities have also made an unequivocal commitment to enhance the management of public expenditure. In particular, the authorities concur with staff's recommendations for revamping the mediumterm expenditure framework process to allow for strategic planning and ensuring that the budget allocations are consistent with the PRS objectives. The external debt management unit is being strengthened and, to prevent recurrence of external debt stress, the authorities will continue to rely mainly on highly concessional loans and grants.

\section{Monetary and exchange rate policies}

12. The authorities reaffirm their commitment to target base money growth for containing inflation as an appropriate policy framework. Headline inflation is expected to decline as oil and food prices fall, enabling the central bank to effectively use its market-based monetary policy instruments, including a target on reserve money. The central bank will establish closer coordination mechanisms with the Ministry of Finance to facilitate liquidity forecasting and foreign exchange sales to mop up excess liquidity emanating from foreign aid financed projects. The authorities are preparing to implement recent MCM's recommendations on bank supervision. They hope that these recommendations will be complemented by the outcome of the joint Bank-Fund FSAP mission of January 2009 in assisting them to finalize the financial sector reform strategy and other policy responses to risks arising from the global financial crisis and the expected decline in export receipts due to lower coffee prices.

\section{Structural reform agenda}

13. Impressive steps have been taken in the implementation of the structural reform agenda. The agenda includes reforming the financial sector, privatizing the coffee sector, and promoting public accountability. To facilitate further reform of the public financial 
management, the Cabinet will adopt a PFM strategy and action plan, phase-in the government's budget law, and step-up rationalization of government bank accounts. In this regard, the authorities appreciate the support from the development partners and would like to stress that this support remains critical for the successful implementation of the reform agenda.

14. The central bank, drawing on the outcome of the MCM and Bank-Fund FSAP missions, will expeditiously implement the financial sector reform strategy once it is established with Fund-Bank support for the broader development of the financial sector. The central bank also intends to vigorously facilitate the development of the financial sector. To that end, it plans to continue with the restructuring of certain banks.

15. As part of the commitment to promote public accountability, Parliament passed the new budget organic law (referred to earlier) in June 2008. It also passed the new central bank charter and the investment code. The authorities are also committed to further reform the coffee sector that accounts for two-thirds of total export revenue and provides incomes to more than half of the population. Also, with the help of the World Bank, they will reform oil procurement and management.

16. The authorities, together with their East African partners, are steadfast in strengthening the regional integration agenda. In this regard, they are expected to adopt the EAC common external tariff and are taking part in the negotiations towards the establishment of an East African Common Market as a follow up to the existing East African Customs Union. To facilitate coordination of government efforts and decisions related to the EAC integration framework, the authorities have established an inter-ministerial committee.

\section{Conclusion}

17. Despite the challenging environment, the authorities are committed to the implementation of appropriate stabilization and structural policies. In the near term, the authorities are determined to focus on sustaining macroeconomic stability, increasing domestic resource mobilization, promoting pro-poor growth, increasing investment in agriculture and key MDG clusters, and implementing the power-sharing agreement to consolidate the peace process. Their commitment to the PRGF-supported program is unwavering, as demonstrated by their satisfactory end-September 2008 program performance. To this end, they request the completion of the first review under the PRGF arrangement, the decision that the country reached the completion point under the HIPC, and debt relief under the MDRI.

18. The authorities are confident that going forward, continued engagement with the Fund and the support of the development partners will enable them to achieve their development goals and provide a sound basis for realizing some of the critical MDGs and consolidating the peace process. 